\title{
Challenges of Biomass Utilization for Bioenergy in a Climate Change Scenario
}

\author{
Emanuelle Neiverth de Freitas ${ }^{1}$, José Carlos Santos Salgado ${ }^{2}$, Robson Carlos Alnoch ${ }^{3}{ }^{\mathbb{D}}$, Alex Graça Contato ${ }^{1}{ }^{(\mathbb{D}}$, \\ Eduardo Habermann ${ }^{3}{ }^{(0)}$, Michele Michelin ${ }^{4}{ }^{\circ}$, Carlos Alberto Martínez ${ }^{3}$ \\ and Maria de Lourdes T. M. Polizeli ${ }^{1,3, *(\mathbb{D})}$
}

1 Department of Biochemistry and Immunology, Faculdade de Medicina de Ribeirão Preto (FMRP), University of São Paulo, Ribeirão Preto 14049-900, São Paulo, Brazil; emanuelleneiverthf@gmail.com (E.N.d.F.); alexgraca.contato@gmail.com (A.G.C.)

2 Department of Chemistry, Faculdade de Filosofia, Ciências e Letras de Ribeirão Preto (FFCLRP), University of São Paulo, Ribeirão Preto 14040-901, São Paulo, Brazil; salgadojcs@hotmail.com

3 Department of Biology, Faculdade de Filosofia, Ciências e Letras de Ribeirão Preto (FFCLRP), University of São Paulo, Ribeirão Preto 14040-901, São Paulo, Brazil; robsonalnoch@usp.br (R.C.A.); eduardohabermann@gmail.com (E.H.); carlosamh@ffclrp.usp.br (C.A.M.)

4 Centre of Biological Engineering (CEB), Gualtar Campus, University of Minho, 4710-057 Braga, Portugal; mimichelin.bio@gmail.com

* Correspondence: polizeli@ffclrp.usp.br

check for updates

Citation: Freitas, E.N.d.; Salgado, J.C.S.; Alnoch, R.C.; Contato, A.G.; Habermann, E.; Michelin, M.; Martínez, C.A.; Polizeli, M.d.L.T.M. Challenges of Biomass Utilization for Bioenergy in a Climate Change Scenario. Biology 2021, 10, 1277. https: / / doi.org/10.3390/ biology10121277

Academic Editor: John Korstad

Received: 11 November 2021 Accepted: 29 November 2021 Published: 6 December 2021

Publisher's Note: MDPI stays neutral with regard to jurisdictional claims in published maps and institutional affiliations.

Copyright: (c) 2021 by the authors. Licensee MDPI, Basel, Switzerland. This article is an open access article distributed under the terms and conditions of the Creative Commons Attribution (CC BY) license (https:// creativecommons.org/licenses/by/ $4.0 /)$.
Simple Summary: The most recent intergovernmental panel on climate change (IPCC 2021) has shown that the human influence on climate change has been unprecedented, predicting a global temperature increase of $1.5^{\circ} \mathrm{C}$ in the earlies 2030s. The burning of fossil fuels has increased the emissions of nitrous oxide $\left(\mathrm{N}_{2} \mathrm{O}\right)$, methane $\left(\mathrm{CH}_{4}\right)$, and carbon dioxide $\left(\mathrm{CO}_{2}\right)$ to the atmosphere, amplifying the greenhouse effect in the last decades. In this scenario, the use of biorefineries, a renewable analog to petroleum refineries, has attracted a lot of attention since they use renewable sources as lignocellulosic feedstocks. However, climate change alters the temperature, rainfall patterns, drought, $\mathrm{CO}_{2}$ levels, and air moisture impacting biomass growth, productivity, chemical composition, and soil microbial community. Here, we discuss strategies to produce fuels and value-added products from biomass in a climate change scenario, potential feedstocks for bioenergy purposes, the chemical composition of lignocellulosic biomass, enzymes involved in biomass deconstruction, and other processes related to biomass production, processing, and conversion. Understanding these integrated factors involved in bioenergy production with plant responses to climate change shows that climate-smart agriculture is the only way to lower the negative impact of climate changes on crop adaptation and its use for bioenergy.

Abstract: The climate changes expected for the next decades will expose plants to increasing occurrences of combined abiotic stresses, including drought, higher temperatures, and elevated $\mathrm{CO}_{2}$ atmospheric concentrations. These abiotic stresses have significant consequences on photosynthesis and other plants' physiological processes and can lead to tolerance mechanisms that impact metabolism dynamics and limit plant productivity. Furthermore, due to the high carbohydrate content on the cell wall, plants represent a an essential source of lignocellulosic biomass for biofuels production. Thus, it is necessary to estimate their potential as feedstock for renewable energy production in future climate conditions since the synthesis of cell wall components seems to be affected by abiotic stresses. This review provides a brief overview of plant responses and the tolerance mechanisms applied in climate change scenarios that could impact its use as lignocellulosic biomass for bioenergy purposes. Important steps of biofuel production, which might influence the effects of climate change, besides biomass pretreatments and enzymatic biochemical conversions, are also discussed. We believe that this study may improve our understanding of the plant biological adaptations to combined abiotic stress and assist in the decision-making for selecting key agronomic crops that can be efficiently adapted to climate changes and applied in bioenergy production. 
Keywords: climate change; abiotic stress; cell wall remodeling; pretreatment; dedicated energy crop; biofuels

\section{Introduction}

There is a global concern about how plants and ecosystems will respond and adapt to new environmental conditions due to climate change. The effects of climate change on plants depend on the interaction of environmental factors essential for plant growth [1]. The increase in the concentration of carbon dioxide in the atmosphere would increase photosynthesis, which in turn contributes to increased plant growth [2]. However, the benefits to plant growth of increased carbon dioxide will probably be overcome by the deleterious impacts of drought [3] and heat stress [4]. Studies of interactions between species and environmental factors can contribute to understanding the adaptive responses of plants to future predicted conditions and the possible impacts of climate change on vegetation and biomass production.

Lignocellulosic biomass is a plant material that is receiving attention as a renewable resource to reduce dependency on fossil-based energy fuels and diminish biofuel feedstock costs [5]. The carbon dioxide captured during photosynthesis is used for biomass growth, and it is commonly balanced with the release of carbon dioxide from bioenergy / biofuel combustion [6]. Thus, the use of lignocellulosic materials does not increase the atmospheric carbon dioxide concentration compared to fossil fuels. However, the changes in climate conditions are projected to impact the growth, development, and yield of lignocellulosic biomass, and since they represent a promising alternative to generate clean energy and mitigate greenhouse gas emissions, their acclimation reactions to climate change should be explored [7].

The plant cell wall is constituted mainly by cellulose, hemicelluloses, and lignin. These components are intrinsically linked, forming a complex architecture that offers little access to the action of enzymes [8]. Therefore, cellulolytic, hemicellulolytic, and ligninolytic systems are necessary when thinking about the formation of fermentable sugars and the final production of bioenergy. In general, these systems are produced and secreted by microorganisms, mainly filamentous fungi, which have developed cellular secretory mechanisms. Several biomasses have been reported as potentially producing bioenergy, such as sugarcane bagasse [9-15], corn residues [16,17], paper sludge, and eucalyptus chips $[18,19]$. This review provides an overview of the impacts of plant responses to abiotic stress in cell wall properties and biomass digestibility, reporting the key challenges to be faced on the use of lignocellulosic feedstocks for bioenergy purposes in climate change scenarios.

\section{Global Climate Changes: Evidence and Causes}

The unequivocal influence of anthropogenic activities on Earth's climate system has modified climate patterns worldwide. The intensification of greenhouse gases emissions such as carbon dioxide $\left(\mathrm{CO}_{2}\right)$, methane $\left(\mathrm{CH}_{4}\right)$, and nitrous oxide $\left(\mathrm{N}_{2} \mathrm{O}\right)$ in the last decades created an additional radiative forcing on climate, amplifying the natural greenhouse effect. As a result, long-term and significant warming trends have been observed since 1980, and the current temperature anomaly is set at approximately $1^{\circ} \mathrm{C}$ above pre-industrial values. However, according to our most accurate climate models, the global average temperature is expected to keep increasing depending on future scenario emissions and may reach $2{ }^{\circ} \mathrm{C}$ if Paris Agreement goals are not achieved [20]. Furthermore, a warmer world will produce more intense and extreme weather events such as droughts, floods, and heatwaves, impacting natural and managed ecosystems in different world regions [21,22]. Therefore, there is urgency for studies that investigate how climate change will impact the biosphere.

The adverse consequences of climate change, as a result of the rise in anthropogenic greenhouse gas emissions, are among the main environmental concerns faced today on our 
planet. The increase in global average temperatures and changes in precipitation patterns are causing more intense extreme climatic events worldwide, which is convincing evidence that global climate change is already occurring, and its effects will become increasingly severe for all living beings [20].

Climate change is affecting natural and managed ecosystems in diverse ways. The multiple components of climate change are estimated to affect all levels of biodiversity [23], from organisms and biomes to societies and human economies [24]. As a result of climate change and extreme weather events, native and cultivated plants will face limited options to avoid habitat loss or extinction: adaptation, migration, or death [25]. These impacts will probably be more intense in developing countries where agriculture and livestock are the main economic activities. In 2009, a group of scientists led by Johan Rockström, from Stockholm University, reported in Nature [26] nine "planetary limits" or safe environmental limits that humanity must respect, and within which it can develop without the impacts caused to the environment being irreversible. Unfortunately, four planetary boundaries of humanity had already been transgressed: climate change, biodiversity loss, land-system change, and biogeochemical flows, while other planetary limits such as the use of freshwater, land-use changes, and ocean acidification were in danger of being overcome [27].

According to the most recent IPCC report (2021), human-induced climate change has led to an increased frequency and/or intensity of climate extremes in every region across the globe. The IPCC report also predicts that global warming will reach $1.5^{\circ} \mathrm{C}$ in the early 2030s, and without reaching net-zero $\mathrm{CO}_{2}$ emissions-along with strong reductions in other greenhouse gases (GHG) such as $\mathrm{CH}_{4}$ and $\mathrm{N}_{2} \mathrm{O}$, the planet will continue to warm. Various consequences of climate change will become irreparable over time, most particularly melting ice sheets, rising sea levels, biodiversity loss, and ocean acidification. Additionally, the impacts will continue to mount and compound as emissions of GHGs increase [20].

Land-use change due to agriculture is the principal cause of global deforestation, which causes a decrease in the volume of water transpired from plant leaves. In the Amazon Basin, the substantial deforestation observed in the last decades, combined with global climate change, is triggering more extreme drought. Besides that, as a result of deforestation and climate change, the carbon sink capacity of the Amazon Forest seems to be in decline. It would cause an abrupt shift from rainforest to savanna, with dangerous consequences for the entire planet [28]. The reduction in fossil-based energy consumption and the replacement with sustainable use of bioenergy from biomass are within the main options to fight climate change, reducing fossil carbon dioxide emissions to the atmosphere. However, biomass production and the potential use of biomass as a energy source are strongly dependent on environmental conditions and how plants respond to environmental changes.

\section{Plant Responses to Climate Change}

Biomass accumulation and its chemical composition are the final results of a complex set of metabolic pathways that respond to environmental changes [29]. It is widely accepted that increased atmospheric $\mathrm{CO}_{2}$ concentration, represented here as $\left[\mathrm{CO}_{2}\right]$, improves plant growth and productivity by direct effects on photosynthesis and other physiological processes [30]. However, the $\mathrm{C} 3$ and $\mathrm{C} 4$ photosynthetic types of plants respond differently to higher $\left[\mathrm{CO}_{2}\right]$. Concerning $\mathrm{C} 3$ species, the higher $\left[\mathrm{CO}_{2}\right]$ positively affects photosynthesis since in this condition, D-ribulose-1,5-bisphosphate carboxylase/oxygenase (Rubisco) speeds up carboxylation reaction and suppresses the oxygenation reaction. Consequently, the energy costs related to $\mathrm{CO}_{2}$ losses are reduced, leading to the accumulation of carbohydrates in leaves and improved biomass production [30]. Nevertheless, as photosynthesis in $\mathrm{C} 4$ species already occurs in saturated conditions of $\mathrm{CO}_{2}$ at the Rubisco active site, $\mathrm{C} 4$ crops would not benefit much from atmospheric $\mathrm{CO}_{2}$ increase [31]. However, some $\mathrm{C} 4$ species are also positively affected by increased atmospheric $\left[\mathrm{CO}_{2}\right]$. For example, Guinea grass (Panicum maximum) plants developed under $600 \mathrm{ppm}$ of $\left[\mathrm{CO}_{2}\right]$ showed an 
increased photosynthetic rate of approximately $25 \%$ when compared to plants growing under $400 \mathrm{ppm}$ of $\left[\mathrm{CO}_{2}\right]$ [32]. A similar response was reported for sugarcane (Saccharum officinarum) [33], in which photosynthesis improved under elevated $\left[\mathrm{CO}_{2}\right]$, leading to higher biomass production. However, in general, the average increase in photosynthesis and productivity is still smaller in C4 plants compared to C3 species [30]. Moreover, this direct relationship between improved photosynthesis and enhanced biomass production is not straightforward since surplus carbon can be translocated to roots, flowers, fibers, and lignin synthesis [32]. In addition to the direct effects of high $\left[\mathrm{CO}_{2}\right]$, photosynthesis and plant biomass production may be improved due to the effects on gene regulation [34], water relations [35], and enzymes [36].

Regarding high-temperature effects, the photosynthetic response of species depends on their optimum growth temperature and the intensity of warming. In general, biomass production and photosynthesis of $\mathrm{C} 4$ grasses under well-watered conditions are greatly improved under a warmer atmosphere [37]. This enhancement is related to higher enzymatic activities, chlorophyll synthesis, and changes in photosystems dynamics [37]. However, some species are susceptible to heat, and the global temperature increase might reduce photosynthetic efficiency due to stomatal closure resulting in minor $\mathrm{CO}_{2}$ flux into leaves through stomata and decreased Rubisco affinity for $\mathrm{CO}_{2}$ with rising temperature [38]. In addition, when the optimum growth temperature is exceeded, the production of reactive oxygen species is intensified, damaging biomolecules, and leading to the disruption of photosynthetic apparatus [39].

Human-caused climate change is modifying different chemical and physical aspects of the atmosphere, including temperature, air moisture, $\mathrm{CO}_{2}$ levels, drought, and rainfall patterns [20]. Therefore, plants will not respond independently to each one of these changing factors, but instead, plant biomass production will respond to a combination of atmospheric factors changing at the same time. In this scenario, unraveling the interactive effects of different climate change factors on biomass accumulation is critical for a deeper understanding of bioenergy production in the future. Unfortunately, multifactorial experimental designs are still scarce in the literature, and some uncertainty remains regarding plant responses to future climate conditions. Some examples reported for Guinea grass indicated that when plants develop under a warmer and $\mathrm{CO}_{2}$-enriched atmosphere, the positive effects of each factor are not additive, and production is not higher than under isolated effects of $\mathrm{CO}_{2}$ or warming [40].

Moreover, elevated $\left[\mathrm{CO}_{2}\right]$ seems to offset part of the negative impacts of drought on plant performance since elevated $\left[\mathrm{CO}_{2}\right]$ reduces stomatal conductance, transpiration, and water absorption from the soil, conserving soil moisture for more time [36,41]. Indeed, in maize (Zea mays), plants growing under elevated $\left[\mathrm{CO}_{2}\right]$ exhibited improved photosynthesis only during periods of drought $[42,43]$. On the other hand, under a $\mathrm{CO}_{2}$-enriched atmosphere, switchgrass (Panicum virgatum) photosynthesis did not increase regardless of soil type [44]. Some experiments also indicate that increased temperature will negate any $\mathrm{CO}_{2}$ stimulation of photosynthesis and productivity in soybean plants (Glycine max) in the Midwest United States [45]. Studies that combine warming, drought, and elevated $\left[\mathrm{CO}_{2}\right]$ together are even rarer, but some experiments suggest no interactions between all three factors in biomass production and photosynthesis of wheat plants [46,47]. Therefore, the use of plant biomass as a source of energy in future conditions of climate change needs to take into account all the future conditions of productivity and composition that will arise from these new environmental conditions.

\section{The Role of Circular Economy in Mitigating Climate Change}

Since the industrial revolution, the world has applied a linear economic model of "take, make, and dispose of" based on the presumption of abundant and inexpensive non-renewable resources [48]. However, total world energy consumption is predicted to increase $48 \%$ from 2012 to 2040, and the linear economic model needs to be replaced, attending to economic demands while preserving environmental needs [49]. The new 
bioeconomic model created in the last decades supports the reuse and recovery of natural resources as an alternative to fossil and non-renewable resources [48]. For this purpose, global research programs have been encouraged to discover new and sustainable energy supply as the global economy can no longer depend on fossil fuels that release considerable amounts of greenhouse gases [50].

The realization of the circular bioeconomic model is based on the biomass-based biorefinery, in which abundantly available and renewable lignocellulosic biomass is converted into fuels and chemicals [48]. The biorefinery concept developed a path forward to a society less dependent on fossil fuels. In addition, it contributed to mitigating climate change, mainly because it is considered to maintain net-zero $\mathrm{CO}_{2}$ emission into the atmosphere because the $\mathrm{CO}_{2}$ generated through the use of the resources is used in biomass production via photosynthesis [6].

A biorefinery represents the renewable equivalent of a petroleum refinery, but with the possibility to use the renewable lignocellulosic feedstocks to produce novel value-added chemicals and fuels that are otherwise not obtainable from fossils (Figure 1) [51]. The International Energy Agency Bioenergy Task 42 defines biorefining as "the sustainable processing of biomass into a spectrum of marketable bio-based products (chemicals, materials) and bioenergy (biofuels, power, heat)" [52]. Nonetheless, achieving this goal requires the selection of microorganisms capable of utilizing biomass as substrate, a deep understanding of the biomass chemistry, and of the environmental effects on the bioenergetic potential of feedstocks, which are crucial for establishing biorefinery systems [6].

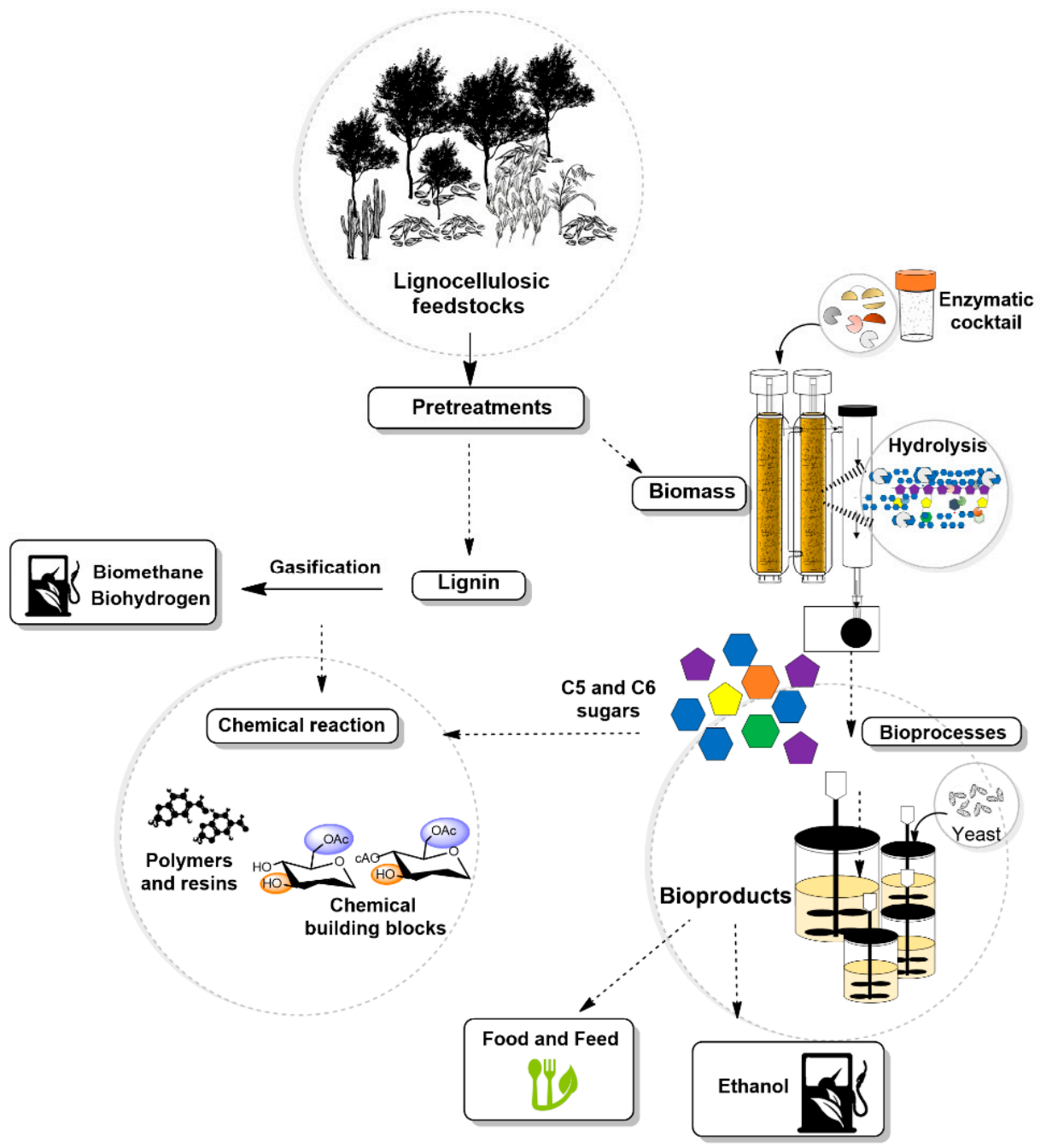

Figure 1. Schematic illustration of the biorefinery concept to produce fuels and chemicals. 
Considering the energy content (USD/GJ), lignocellulosic materials have their cost estimated to be $50 \%$ lower than another feedstock, as crude oil, natural gas, corn kernels, and soy oil $[50,53]$. The high production and low cost of lignocellulosic biomass confirm its potential as an abundant source for bioenergy generation. In terms of economic evaluation, fine chemicals and other commodities that are derived from lignocellulosic biomass are the ones with the highest potential to maximize the value of the bioenergetic chain since the products can be applied in various economic sectors (e.g., pharmaceutical, petrochemical, construction, automotive, cosmetics, agroindustry, and others). At the second valuation are the biofuels and materials, followed by energy commodities, fertilizers, and pesticides [54].

Second-generation or cellulosic ethanol is the biofuel with the highest potential to substitute fossil fuels since it is possible to increase the biomass yield without altering the area used to cultivate the feedstocks by using previously discarded plant wastes. Considering the worldwide basis, the cellulosic ethanol market is predicted to achieve 27 billion gallons/year by 2022, translating the world's strong demand for second-generation ethanol [55]. In addition, a couple of other products produced in biorefinery have significant interest due to their commercial uses, such as succinic, fumaric, malic, and glutamic acid, glycerol, sorbitol, and xylitol/ arabinitol, which nowadays are formed through the highvalue replacement products [51].

\section{Potential Feedstocks for Bioenergy Purposes}

The production of the first generation (1G) ethanol and biodiesel raised a concern about fuel vs. food conflict since it depends on the utilization of food crops to produce sucrose, starch, grains, and vegetable oils, impacting food supply and land sustainability [56]. Differently, billions of tons of lignocellulosic materials are produced every year around the world; however, most of these residues are burned or discarded, while it could be converted to second-generation $(2 \mathrm{G})$ ethanol and other value-added products due to the rich carbohydrate fraction $[6,48]$. The main advantage of $2 \mathrm{G}$ ethanol over first-generation fuels is that the former does not compete for fertile lands used in food crop production [57].

Although lignocellulosic materials are potential sources for the production of $2 \mathrm{G}$ fuels, some factors threaten the economic viability of biomass preprocessing and must be considered when choosing a feedstock for bioenergy production, such as (I) biomass availability; (II) the nutrient input during the growing season; (III) the logistics of biomass collection, storage, and transportation; (IV) chemical composition; (V) calorific value; and (VI) potential ethanol yields [56,57]. Moreover, biomass employment as an energy source will depend on considering these factors to a particular region since most of them are influenced by the climate and growing conditions [58].

Furthermore, lignocellulosic feedstocks used in biorefineries can be classified into primary categories: (1) residues and wastes and (2) dedicated energy crops. Residuals and agricultural wastes are mainly derived from household practices, manufacturing, and agriculture [59]. Residue materials include organic matter, plastics, and municipal solid wastes, which are most useable due to the methane stored in the material. Furthermore, they have a heterogeneous nature, frequently containing plastics, metals, and glass, along with high transportation costs, making difficult its use as a biorefinery feedstock [59]. Agriculture wastes include residues generated after crop harvest or in the processing of food crops [54]. The most important cellulosic feedstocks are sugarcane bagasse, corn stover, wheat, rice, barley straw, and sorghum stalks $[8,11,16,17,54]$. All of them are produced in considerable amounts and have the advantage of being made along with the food crop without requiring additional costs. However, part of the biomass must be left in the field for soil incorporation, reducing the amount available for bioenergy purposes [54,59].

Dedicated energy crops are cultivated for energy conversion processes without replacing food crop production. They can be classified into herbaceous and short-rotation woody crops [58,59]. Short-rotation woody crops include soft and hardwoods with a harvest cycle of five to eight years, being eucalyptus and poplar the main species with bioenergy potential. Herbaceous energy contains little woody content and represents an important 
alternative for diversification of feedstock, helping to expand the energetic matrix beyond the agriculture wastes [58,59]. Perennial grasses, such as Miscanthus and switchgrass, are widely applied as energy crops in Europe and the United States, but other grassy biomasses also have demonstrated significant potential as bioenergy crops like the ones from the Panicum genus, which has high biomass production (30 ton/ha) and great ethanol yield $8571.0 \mathrm{~L} / \mathrm{ha}[50,60]$.

The use of perennial grasses for biofuel and biorefinery purposes has some advantages as high biomass yield, broad geographic adaption, low lignin content, easy hemicelluloses degradation, and production during the intercropping period to avoid intermittent biofuel production $[50,61]$. Moreover, they have low mineral-nutrient inputs making it possible to grow in lands abandoned for agriculture uses, not requiring extensive capital-intensive processes, making the final product economically feasible [62].

\section{Chemical Composition of Lignocellulosic Biomass}

Lignocellulose is a material synthesized by plants to form a thick layer named the cell wall, which is present in all cell types protecting against pathogens [50]. Polymeric carbohydrates (cellulose and hemicellulose) and lignin are the primary constituents of lignocellulosic biomass with minor amounts of proteins, pectin, extractives, and inorganic compounds. Nonetheless, the ratios among cell wall components and their structure will depend on several factors such as age, species, and culture conditions [63].

Cellulose represents $25-50 \%$ of total lignocellulosic dry matter, while hemicellulose represents $20-40 \%$, and lignin constitutes $15-25 \%$ of the entire content [64]. The cellulosic component is composed of linear $\beta-1,4$-glucan chains that are tightly packaged into microfibrils and generally divided into two regions, one with low molecular order (called amorphous cellulose) and the other with high crystalline order (called crystalline cellulose). Likewise, the polymerization degree in cellulose is the highest among the lignocellulosic polymers and could range from 100 to 10,000 depending on its source, being responsible for cellulose's low flexibility [65].

Hemicellulose polymers are branched heteropolysaccharides mainly composed of residues of xylose, arabinose, glucose, and mannose, which hold some functional groups such as methyl, acetyl, glucuronic, and galacturonic cinnamic acids [66]. Van der Waals interactions and hydrogen bonds are the main forces between cellulose microfibrils, whereas hemicelluloses bind cellulose fibrils to the surface through non-covalent linkages [63]. Lignin is produced to provide structural reinforcement to the plant tissue, and it consists of a phenylpropanoid polymer mainly derived from three monolignols units: p-coumaryl alcohol (H), coniferyl alcohol (G), and sinapyl alcohol (S), which may differ between species and cell tissue type. The differences in monolignols composition substantially affect the deconstruction of biomass and delignification [66]. Meanwhile, lignin polymeric structures are assumed to arise from the polymerization reaction of phenoxy radicals formed by oxidative enzymes in the cell wall [67].

The cell wall constituents are intertwined with each other forming a complex and recalcitrant structure. Zhang [68] found that only $0.0023-0.041 \%$ of the $\beta-1,4$-glycosidic bond of cellulose is accessible for enzymatic degradation. Hemicellulose is easier than cellulose to hydrolyze, whereas lignin polymer is resistant to hydrolysis and cannot be fermented to produce ethanol, being used in chemicals and resins production as part of the biorefinery process $[50,64]$.

Furthermore, ferulic acid, generated through the phenylpropanoid pathway, can couple oxidatively with lignin and, due to its carboxylic group, can esterify arabinose residues from hemicelluloses establishing lignin carbohydrate complex (LCC) (Figure 2) [69]. Thus, the formation of LCCs has an excellent contribution to cell wall recalcitrance against biological and chemical degradation. Other possible reasons for this resistance are (I) low accessibility of crystalline cellulose fiber that prevents cellulase attack and is also reported to have a role in cellulase adsorption and processivity and (II) the presence of hemicellulose 
and lignin on the surface of cellulose blocks the enzymatic access to the substrate, which is required for bioconversion of cellulose to glucose [70,71].

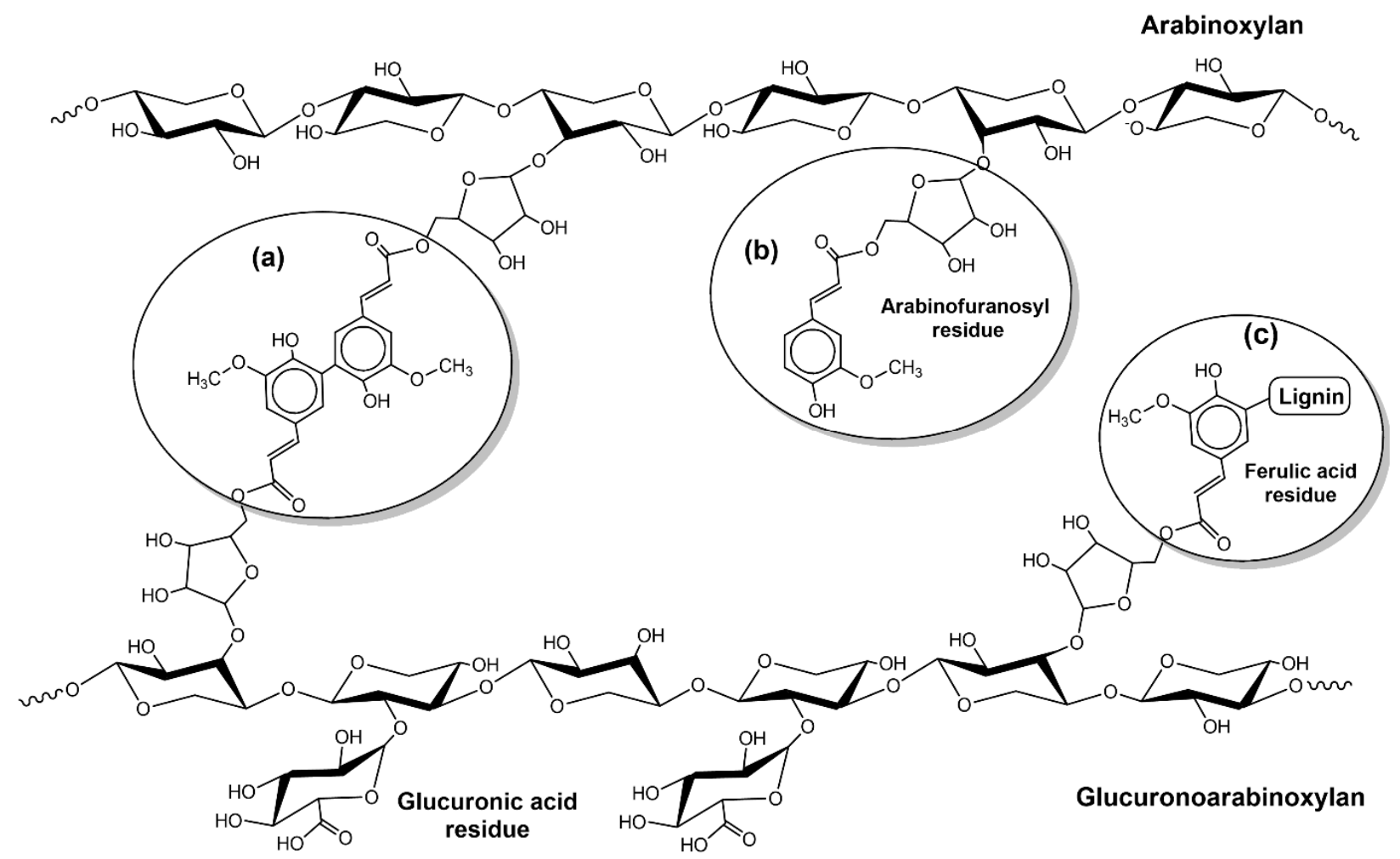

Figure 2. Ferulic acid esterified with arabinofuranosyl residue of glucuronoarabinoxylan (GAX) (a); cross-linking involving diferulic acid (b); ferulic acid residue attaching lignin to GAX forming lignin carbohydrate complex (LCCs) (c).

\section{Pretreatment}

The low saccharification rate of cellulose in lignocellulosic biomass is mainly promoted by the steric hindrance imposed by lignin, hemicellulose, and crystalline morphology of cellulose. Usually, in the native form, less than $2 \%$ of the polysaccharides from lignocellulosic biomass are hydrolyzed by enzymes. Therefore, pretreatment is a crucial step in the lignocellulosic-based industry to reach a high conversion of cell wall polysaccharides into fermentable sugars [50].

Nonetheless, pretreatment is the most energy-demanding step in biomass conversion and can contribute to more than $40 \%$ of the total processing [72]. This challenge has encouraged the investigation for technologies to achieve scalable, efficient, and greener pretreatments. The main goals for biomass pretreatment are to remove and preserve the hemicelluloses and lignin and to reduce the crystallinity index of cellulose and increase the cellulases accessibility [73].

Generally, the pretreatment methods are divided into four categories: physical, chemical, physicochemical, and biological (Figure 3). Combinations of two or more methods have also been described in the literature. Nevertheless, it is difficult to define an ideal pretreatment, although some examples are reported in literature according to hemicelluloses or lignin removal and cellulose conversion (Table 1). An effective pretreatment should allow high carbohydrates recovery; avoid or limit the formation of inhibitors or sugar degradation; enable to value all compounds present in lignocellulosic materials, not only cellulose; minimize energy input; employ green solvents; limited generation of wastes; and be cost-effective [74,75]. 


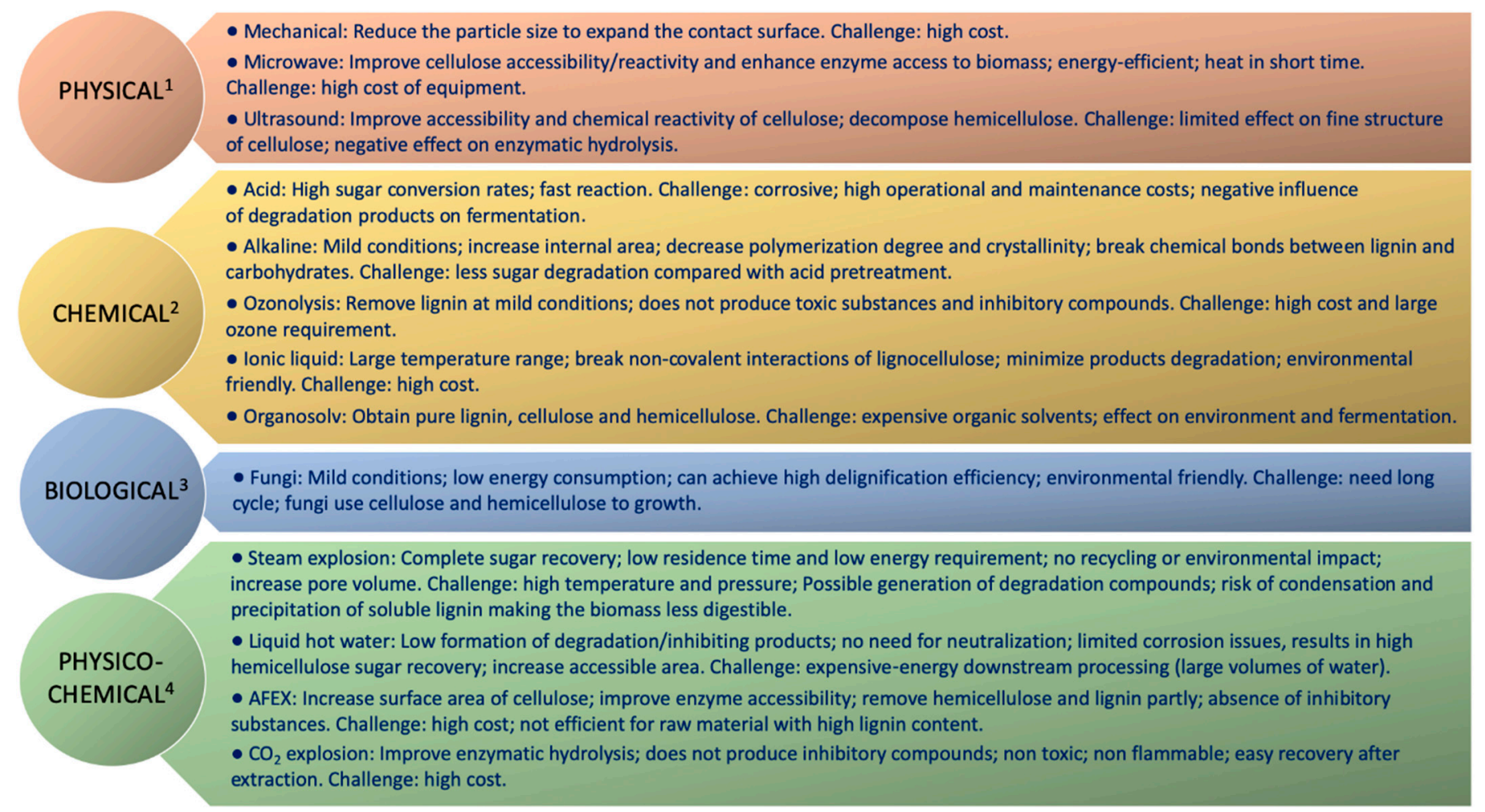

Figure 3. Advantages and challenges of the different pretreatment technologies.

Among the factors that could influence pretreatments effects on biomass that are usually considered in the severity factor of the pretreatment (temperature, time, and $\mathrm{pH}$ ), the $\mathrm{pH}$ significantly affects this step [76]. At low $\mathrm{pH}$, most hemicelluloses are removed from the solid material and released as monomeric sugars, while cellulose is kept almost intact. Working at neutral or around neutral $\mathrm{pH}$ leads to partial hemicelluloses hydrolysis due to organic acid formation resulting in the autohydrolysis process; still, most hemicellulose stays in oligomeric form since the conditions are not severe enough. In contrast, lignin is dissolved at mild acidic ( $\mathrm{pH}$ ) and alkaline $\mathrm{pH}$, while most cellulose and hemicellulose are retained in the solid fraction [51]. Consequently, the selection of the pretreatment method depends on the final application.

The employment of ligninolytic enzymes in biological pretreatment is a potential alternative to the pretreatment step since it does not require high energy demand and no chemical is applied in the process; however, their production costs need to be considerably reduced [77]. The on-site production of ligninolytic enzymes is an alternative to reduce production and operation costs significantly [78]. Metabolic engineering of microbial strains of industrial interest constitutes a tool that modifies the protein expression and regulation, increasing the yield of ligninolytic enzymes. Some examples of successfully engineered strains to improve ligninolytic enzyme production are discussed in Li et al. $(2016 a, 2016 b)[79,80]$. 
Table 1. Effect of different pretreatments on the breakdown of lignocellulose biomass and the enzymatic conversion of cellulose into glucose, with emphasis on grasses.

\begin{tabular}{|c|c|c|c|c|c|c|}
\hline Biomass & Pretreatment & Details & Conditions & Maximal Removal (\%) & Glucose Yield (\%) & Reference \\
\hline $\begin{array}{c}\text { Miscanthus (Mx2779 } \\
\text { and Mxg) }\end{array}$ & Steam explosion & & $\begin{array}{c}180 \text { ( } 9 \text { bar }), 200 \text { ( } 15 \\
\text { bar), } 210 \text { ( } 20 \text { bar }) \text {, and } \\
225^{\circ} \mathrm{C}(25 \text { bar }) \text { for } 5, \\
10, \text { or } 15 \mathrm{~min}\end{array}$ & $\begin{array}{c}73.2 \% \text { xylan }(\mathrm{Mx} 2779) \\
78.9 \% \text { xylan }(\mathrm{Mxg}) \\
200^{\circ} \mathrm{C}, 15 \text { bar, } 10 \mathrm{~min}\end{array}$ & $\begin{array}{l}68 \%(\mathrm{Mx} 2779) \\
41 \%(\mathrm{Mxg})\end{array}$ & [81] \\
\hline $\begin{array}{l}\text { (1) Switchgrass } \\
\text { (2) Corn stover } \\
\text { (3) Miscanthus }\end{array}$ & $\begin{array}{c}\text { Microwave-assisted } \\
\text { DES }\end{array}$ & ChCl:lactic acid (1:2) & $45 \mathrm{~s}, 800 \mathrm{~W}\left(152^{\circ} \mathrm{C}\right)$ & $\begin{array}{l}\text { 83.7\% xylan } 72.2 \% \text { lignin } \\
90.1 \% \text { xylan } 79.6 \% \text { lignin } \\
77.5 \% \text { xylan } 65.2 \% \text { lignin }\end{array}$ & $\begin{array}{l}75 \% \\
<40 \% \\
78.5 \%\end{array}$ & [82] \\
\hline Switchgrass & DES & $\begin{array}{l}\text { ChCl:glycerol }(1: 2) \\
\text { with } 20 \mathrm{wt} \% \text { water } \\
\text { additions }\end{array}$ & $120^{\circ} \mathrm{C}$ for $1 \mathrm{~h}$ & $\begin{array}{l}85.35 \% \text { xylan } \\
56.82 \text { lignin }\end{array}$ & $89 \%$ & {$[83]$} \\
\hline $\begin{array}{c}\text { Elephant grass } \\
\text { (leaf, stem, and whole } \\
\text { plant) }\end{array}$ & Acid & $\mathrm{H}_{2} \mathrm{SO}_{4}$ & $\begin{array}{l}5,10 \text {, or } 20 \% \mathrm{H}_{2} \mathrm{SO}_{4} \text { at } \\
121^{\circ} \mathrm{C} \text { for } 30 \mathrm{~min}\end{array}$ & $\begin{array}{l}\text { 85.02\% hemicellulose from leaf } \\
\qquad\left(20 \% \mathrm{H}_{2} \mathrm{SO}_{4}\right)\end{array}$ & $89.2 \%$ (leaf, $20 \% \mathrm{H}_{2} \mathrm{SO}_{4}$ ) & [84] \\
\hline Miscanthus & Biological & Bacteria (laccase) & $\begin{array}{c}37^{\circ} \mathrm{C}, 200 \mathrm{rpm}, 96 \mathrm{~h} \\
\text { (with a mediator) }\end{array}$ & $\begin{array}{c}\text { 59.5\% lignin } \\
\text { (Pseudomonas sp.) }\end{array}$ & $87 \%$ & [86] \\
\hline
\end{tabular}




\section{Enzymatic Deconstruction of Lignocellulosic Biomass}

After the pretreatment step, the biomass needs to be broken down into monomeric (C5 and C6) sugars that can be converted into ethanol or other chemicals through the fermentation process. The degradation of lignocellulosic material into simple sugars can occur either enzymatically or chemically. Although the enzymatic process is still under development to achieve economic feasibility, it has been shown to be the best choice over the past few years as it is, by nature, a more specific and ecological process. In this way, by presenting milder operating conditions, there is a reduction in the formation of inhibitory biological compounds $[10,15,87]$.

The high complexity and association of the carbohydrate-lignin complex in the plant cell walls is the main obstacle in the bioconversion of lignocellulosic materials into fermentable sugars, requiring diverse enzymes with different functions Although microorganisms, especially fungi, are great enzyme producers, the enzymatic extracts from a single microorganism do not have all enzymes necessary to degrade cellulosic materials optimally, considering the conversion rate greater than $70 \%$ in $48 \mathrm{~h}$ of hydrolysis with more than $10 \%$ solids load in low enzyme load [73].

Consequently, adding extracts from various microbial sources is essential to improve enzymatic hydrolysis efficiency [88]. The fungal strains with the greatest industrial interest for cellulolytic enzymes are the genera Trichoderma, Penicillium, and Aspergillus. They are described as producing the main cellulolytic enzymes such as cellobiohydrolases, endoglucanases, and $\beta$-glucosidases, and other essential enzymes for biomass deconstruction [89].

For the conversion of lignocellulosic biomass into fermentable sugars to occur in a viable way, some challenges must be overcome for commercial applications, such as (I) reduce costs of enzyme production; (II) selection of suitable enzyme sets with the optimal amount of each enzyme to optimize synergistic effects; (III) enzymes that can function effectively at high solid biomass loads; (IV) improvement of enzyme catalytic efficiency; and $(\mathrm{V})$ reduction of the inhibition of the $\beta$-glucosidases final product $[78,90]$.

Furthermore, the composition and structure of biomass have a considerable influence on enzymatic hydrolysis and can be altered under future climate conditions. Therefore, knowing the effects of climate on biomass structure, along with choosing the pretreatment category to be applied, are essential parameters to be considered for the development of the enzymatic cocktail [73].

The enzymes that should be composing enzymatic cocktails necessary for the complete hydrolysis of lignocellulose feedstock are core cellulolytic, hemicellulolytic, and accessory enzymes. These enzymes are included in different CAZy families and are discussed below (Figure 4).

\subsection{Core Cellulolytic Enzymes}

At least three classes of cellulolytic enzymes are essential for the enzymatic hydrolysis of cellulose: endo- $\beta-1,4$-glucanases (EC 3.2.1.4), cellobiohydrolases, or exoglucanases (EC 3.2.1.91) and $\beta$-glucosidases (EC 3.2.1.21)). The cellobiohydrolases are composed of two families: cellobiohydrolases I and II, which act on the $\beta-1,4$-glycoside bonds at the reducing and non-reducing ends of the cellulose, respectively, releasing cellobiose. Endoglucanase (EC 3.2.1.4) hydrolyzes $\beta$-1,4-glycosidic bonds in amorphous regions of cellulose, while $\beta$-glucosidases (EC 3.2.1.21) act on cellobiose and cellodextrins to release glucose. $\beta$-glucosidases play a key role as catalysts in lignocellulosic degradation since this enzyme releases glucose, used by Saccharomyces cerevisiae in the fermentation process for the production of ethanol, for example [91]. 
A)

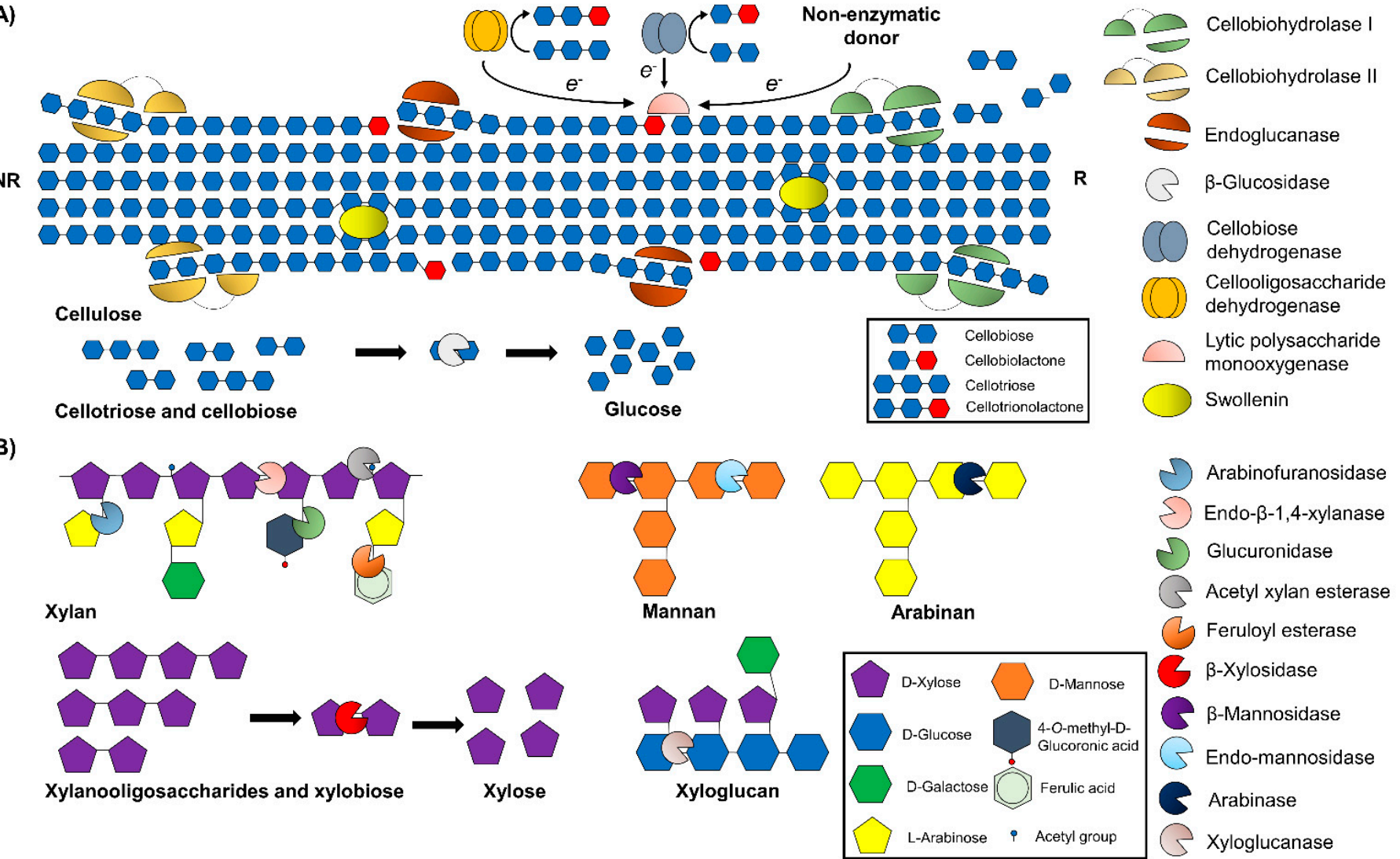

Figure 4. Representation of current view in cellulose and hemicellulose enzyme degradation. Enzymes from the core cellulase mixture and accessory enzymes involved in cellulose degradation. (A) Hemicellulolytic enzymes and accessory enzymes involved in hemicellulases debranching and degradation (B). NR: non-reducing end, R: reducing end.

\subsection{Hemicellulolytic Enzymes}

Since hemicellulose is a hetero and branched polymer composed of different monomeric units and functional groups, its debranch and degradation to C6 and C5 sugar need the cooperation action of numerous enzymes (Figure 4). These enzymes assist in hemicellulose removal and increase the effectiveness of cellulase's attack by exposing the cellulose microfibrils [92].

The enzymes endo- $\beta-1,4$-xylanase and (EC 3.2.1.8) and $\beta$-D-xylosidase (EC 3.2.1.37) are the most important xylan-degrading enzymes, especially for arabinoxylan (AX) from grasses. While endo- $\beta-1,4$-xylanase cleaves glycosidic linkages in the internal part of the xylan backbone, releasing xylose and xylooligosaccharides, the $\beta$-D-xylosidase enzyme hydrolyzes $\beta$-1,4-D-xylans, xylooligosaccharides, and xylobiose from nonreducing ends, releasing xylose as the product $[73,93]$.

The hydrolyze of L-arabinoses units from heteropolysaccharides requires the action of arabinases (EC 3.2.1.99) and arabinofuranosidases (EC 3.2.1.55). Arabinases act in the $\alpha-1,5$-arabinofuranosidic bonds between arabinose residues present on arabinan to release arabinose in mono or oligomeric form [94]. Arabinofuranosidases hydrolyze, from the nonreducing end, the $\alpha-1,2, \alpha-1,3$, and $\alpha-1,5$ - glycosidic linkages in arabinan, arabinoxylan, and arabinogalactan to arabinofuranosidic residues [95].

As previously discussed, glucuronic acid residuals are also part of hemicelluloses, as glucuronans and glucuronoglycan. $\beta$-glucuronidases (EC 3.2.1.31) hydrolyze glucuronic acid [96].

Xyloglucan endo- $\beta$-1,4-glucanases (EC 3.2.1.151) involve the hydrolyze of xyloglucan hemicellulases, consisting of a $\beta-1,4$-glucan backbone with xylosyl side chains linked at O-6 position of glycosyl residue [91]. 
Finally, for the deconstruction of mannan hemicelluloses, which are formed by a linear backbone of D-mannose/glucose with galactosyl side groups, endo-1,4- $\beta$-mannosidase (EC 3.2.1.78) and $\beta$-mannosidases (EC 3.2.1.25) are needed. The former hydrolyzes linkages in the mannans' backbone, whereas the latter hydrolyze mannans from the nonreducing end [97].

\subsection{Accessory Enzymes}

Besides the enzymes mentioned above, the enzymatic cocktail should also cover accessory enzymes such as feruloyl and acetyl esterases and lytic polysaccharides monooxygenases, and proteins, such as expansins, to completely degrade lignocellulose substrates. These enzymes have been described to assist biomass deconstruction by opening up the lignocellulosic matrix and acting synergistically with the canonical hydrolytic enzymes, allowing extraction of more bioenergy power from lignocellulosic biomass and helping to reduce the costs [98].

Among auxiliary activity enzymes, AA9 (formerly GH61), a lytic polysaccharide monooxygenase (LPMO), has been reported mainly in the fungal system. The AA9 is copper-dependent and cleaves cellulose chains by an oxidative mechanism either in $\mathrm{C} 1$ or C4 carbon of glucose in the cellulose chain, requiring an electron donor and molecular oxygen [99]. Fungi also secrete a diversity of carbohydrate-specific oxidoreductases classified in auxiliary activity family 7 (AA7). The most known are cellobiose dehydrogenase and cellooligosaccharide dehydrogenase (CDHs), catalyzing the oxidation of the reducing end $\mathrm{C} 1-\mathrm{OH}$ in cellooligosaccharides and cellobiose to the corresponding lactones, donating electrons to LPMOs in the process. Lactose, xylooligosaccharides, and chitooligosaccharides could also be converted to lactones by the enzymes of the AA7 family [98]. Furthermore, the combined action of AA7, AA9 with hydrolytic enzymes has been demonstrated to result in higher levels of sugar release since AA9 acts creating reactive sites for cellulases on the recalcitrant crystalline regions, with low levels of monomeric sugars released [100].

Acetyl xylan esterase (EC 3.1.1.72) catalyzes the deacetylation of xylans and xylooligosaccharides by removing $O$-acetyl substitutes from the C-2 and C-3 positions [101]. Feruloyl esterases (EC 3.1.1.73) act on carboxylic ester linkages between arabinose and ferulic acid side groups forming the lignin-carbohydrate complexes (LCCs). As previously described, LCCs significantly reduce biomass recalcitrance by hiding cellulose microfibrils to the hydrolytic attack of CAZy enzymes [97].

Another class of accessory enzymes is the non-hydrolytic/non-oxidative proteins, known for their amorphogenesis-inducing action. These enzymes disturb the plant cell wall structural matrix, facilitating the deconstruction of the polysaccharides by hydrolytic and oxidative enzymes [102]. Swollenin is an example of such a protein that targets the amorphous regions of cellulose, weakening hydrogen bonding with hemicellulose rather than directly disrupting the crystalline regions [103]. Therefore, by promoting substrate amorphogenesis, swollenin increases plant cell wall porosity and provides the catalytic enzymes enhanced access to the glycosidic linkages within the sugar polymers.

Laccases, lignin peroxidases, and manganese peroxidases are also accessory enzymes responsible for lignin depolymerization and chemical modification [104]. Generally, it is preferred to be added before enzymatic hydrolysis during biological pretreatment of biomass to avoid the formation of lignin-derived compounds that could impact the enzymatic hydrolysis of cellulose and fermentation [105].

\section{Challenges of Biomass Utilization for Bioenergy in a Climate Change Scenario}

The agricultural industry and climate change are uniquely dependent on each other since the abiotic and biotic stresses caused by environmental changes have adverse effects on plants. The increment of average temperature, heat waves, change of $\mathrm{CO}_{2}$ atmospheric levels, variations in annual rainfall, and drought, distress plant development, and yield, comprising biochemical, physiological, molecular, and morphological modifications of plants [1,106]. 
In the climate change scenario, lignocellulosic biorefinery could be strongly impacted since climate change has been described to affect biomass growth, productivity, chemical composition, and soil microbial community [1,107-110] (Figure 5). Therefore, since the major feedstocks for lignocellulosic biorefinery are dedicated energy crops (e.g., switchgrass, Miscanthus giganteus, Guinea grass, energy cane, and others), or plant residues (e.g., sugarcane bagasse, corn (maize) stover, wheat straw, and others), climate change and the abiotic stress caused by them might significantly impact the production of cellulosic ethanol and other value-added commodities by reducing the yield and availability of these sources of biomass, along with changes in metabolic pathways.

\section{CHALLENGES IN USING LIGNICELLULOSIC BIOMASS FOR BIOENERGY PURPOSES IN CLIMATE CHANGE SCENARIO}

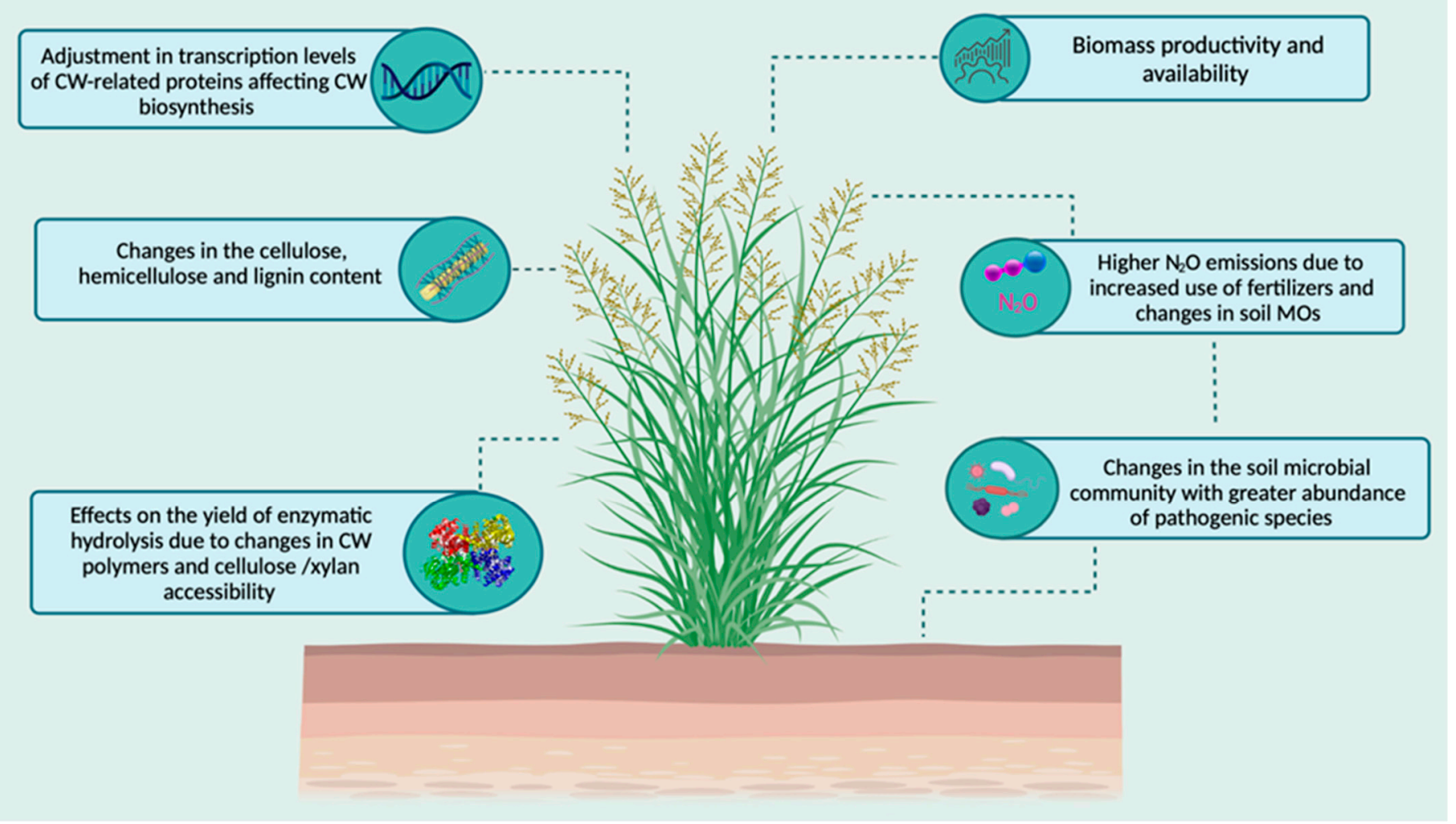

Figure 5. Summary of the main effects of climate change affecting the use of lignocellulosic biomass as feedstock for bioenergy production. CW: cell wall; MOs: microorganisms.

Among climate changes, drought and warming have the greatest negative effect on crop yield [111]. Results from different methods consistently exhibited a negative effect of the rise in global temperature on maize and wheat yield. Without the effect of $\mathrm{CO}_{2}$ fertilization, genetic improvement, and effective adaptation, each degree-Celsius increase in global mean temperature would reduce global yields of maize by $7 \%$ and wheat by $6.0 \%$, on average $[7,107,112]$. In addition, as sugarcane is a relatively high water-demanding crop, water deficiency can lead to up to $60 \%$ in productivity losses [109].

Furthermore, recent evidence has shown that combined stresses might affect plant metabolism differently from isolated stress, showing unique responses [1,110]. As climate changes will be experienced as combined stresses, their effects under real field conditions must be studied. Combined effects of elevated temperature and $\mathrm{CO}_{2}$ enrichment showed that photosynthetic rates of maize are not responsive to increased levels of $\mathrm{CO}_{2}$, due to the concentrating mechanisms of $\mathrm{C} 4$ plants. However, as $\mathrm{CO}_{2}$ enrichment leads to 
improved water relations, the growth rates of maize can be positively affected under $\mathrm{CO}_{2}$ elevated concentrations, but this positive effect is much smaller in $\mathrm{C} 4$ than for $\mathrm{C} 3$ plants [113]. Furthermore, if temperature increase in levels higher than optimum plant growth temperature, $\mathrm{CO}_{2}$ enrichment becomes deleterious and can exacerbate the negative effects of elevated temperature since the stomatal closure induced by $\mathrm{CO}_{2}$ contributes to elevating leaf temperature due to reduced evapotranspiration rates [114]. In this case, elevated temperature and $\mathrm{CO}_{2}$ enrichment would result in lower maize yields [110,114].

Hatfield et al. (2011) [113] concluded that future increases in temperature and $\mathrm{CO}_{2}$ would result in a minimum of 3\% decrease in maize under well-watered conditions. Even for C3 plants, such as wheat and eucalyptus, the beneficial effects of $\mathrm{CO}_{2}$ enrichment on carbon fixation and yields diminish at elevated growth temperatures and might disappear at intensely elevated temperatures [114].

Considering the combined stress of drought and elevated temperature, the effects of drought outweigh the effects of temperature and the stomatal remain closed, leading to reduction of wheat and maize photosynthesis rate, plant length, leaf area, total dry weight, and yield $[115,116]$. Moreover, under warming and water stress the C4 Guinea grass maintained the leaf biomass production in similar levels of current environment conditions (control group) [117].

Likewise, when Guinea grass was developed under warming and $\mathrm{CO}_{2}$-enriched atmosphere $(\mathrm{eTeC})$, although elevated $\mathrm{CO}_{2}$ reduced the foliage by favoring biomass partitioning to steam and accelerated leaf maturation, the effect of elevated temperature partially offset $\mathrm{CO}_{2}$ negative effect and led to comparatively high leaf production in eTeC [118]. Leaf dry Guinea grass biomass was found to be $42 \%$ higher under eTeC conditions, possibly due to the stimulus of starch exportation and the carbon surplus provided by enhanced photosynthesis [32]. In addition, although Guinea grass productivity is expected to rise under $\mathrm{eTeC}$ conditions in well-watered conditions [119], the nutritional requirement for $\mathrm{Ca}, \mathrm{N}$, and $\mathrm{S}$ are also expected to increase, which can lead to an increase in fertilizers and harvesting costs [40].

Furthermore, plants belong to an ecosystem interacting with multiple microorganism communities, which are also affected by climate change. Studies have shown that climate changes would affect soil microbial diversity, abundances, and activities [120-122]. Oliveira et al. (2020) [123] studied the impact of warming and drought on fungal communities showing that under these conditions some phytopathogenic fungi, like Curvularia, Albifimbria, and Fusarium species were more abundant. Some of these species are correlated with seedling's death, grain and seedling rot, and reduced growth in a variety of host crops [124]. Furthermore, Fusarium and Albifimbria genus are widely recognized as nitrous oxide $\left(\mathrm{N}_{2} \mathrm{O}\right)$ producers, a greenhouse gas described as much more dangerous than $\mathrm{CO}_{2}$ for the environment $[125,126]$.

The way that plants are going to react to climate changes is difficult to predict. The crop species, the intensity, and durability of stresses, the geographic location, the optimum temperature of growth, the plant cultivar, are factors that influence plant response [1,112]. Therefore, experimental studies with a combination of stresses that simulate a realistic future climate scenario for major crops will be crucial and strategic to predict the gains or losses that humanity will have from global climate change.

The aforementioned crops, such as maize, sugarcane, and wheat are widely cultivated for food supply, representing important sources that can be used as sources of lignocellulosic biomass, like sugarcane bagasse, wheat straw, and corn stover. Therefore, the reduced yield derived from plant response to climate change might impact both food and bioenergy supply. In this sense, the use of dedicated energy crops as forage grasses represents an important alternative to bioenergy production since these plants seem to have high optimum growth temperature and several mechanisms of adjustment under abiotic stress induced by expected futuristic climate conditions, resulting in higher yields in the future climate scenarios and other advantages mentioned in Section 5. However, 
increased biomass accumulation of grasses under warming is strongly dependent on soil moisture levels and can be nullified with drought spells [117].

Despite the yield, several factors must be considered regarding climate change since environmental conditions might affect the composition of the plant's organic matter, impacting the quality of crops as food and the lignocellulosic composition for bioenergy applications [127] (Figure 5). As plant cell wall represents the main sink for the carbon fixed in photosynthesis, its biosynthesis is controlled by photosynthetic rate and the carbon status of the plant, being dynamically regulated as a response to environmental stresses induced by climate change [128,129].

Cell wall $(\mathrm{CW})$ remodeling represents an important stress tolerance mechanism, some reports reported that significant changes in cell wall might be driven by abiotic stress to maintain growth and productivity [130-132]. Cellulose synthesis has been found to be affected in distinct levels by abiotic stresses such as heat, drought, and $\mathrm{CO}_{2}$ enrichment. An increase of $14 \%$ in cellulose content was found for Guinea grass under eTeC conditions, while $19 \%$ and $22 \%$ higher cellulose content were observed in sugarcane and Arabidopsis, respectively, under elevated $\mathrm{CO}_{2}$ concentrations $[33,133,134]$.

In the non-cellulosic fraction of cell wall, the substitution of arabinose in the xylose backbone, indicated by the xylose: arabinose ratio was reduced for Guinea grass and coffee leaves under heat regardless of the $\mathrm{CO}_{2}$ concentration $[135,136]$. In contrast, in wheat grain arabinose substitution degree increased under heat stress [137]. The xylose: arabinose ratio is a critical parameter for biomass recalcitrance since arabinose can esterify with lignin, forming lignin-carbohydrate complexes (LCCs), which play a key role in reducing the accessibility to hydrolytic enzymes [138].

As for CW polysaccharides, the content and composition of lignin were also found to be responsive to abiotic stress induced by climate change. Under $\mathrm{CO}_{2}$-enriched atmosphere $(\mathrm{eTeC})$ or water stress $(\mathrm{eTwS})$, the lignin content of Guinea grass leaves was 16 and $17 \%$ higher for eTeC and eTwS, respectively $[117,139]$. Temperature is recognized as a crucial factor controlling the lignification process of plant tissues [140]. Even with the higher productivity induced by warming under well-watered conditions, lignin increase may modify industrial processes related to the use of grasses as a bioenergy source.

In contrast, an increase in levels of sinapic acid, phenylalanine, and $\alpha$-Tocopherol were found under warming conditions, which was pointed to impact lignin composition by increasing the content of S-type units [34]. Freitas et al. (2020) [136] proved it, in which Guinea grass under elevated temperature conditions (warmed by $2{ }^{\circ} \mathrm{C}$ above current temperature) presented higher S lignin and S/G ratios, demonstrating a positive effect of temperature for hydrolysis since $S$ lignin is described to easily hydrolyze upon pretreatment step. In Eucalyptus, drought stress disrupted lignin deposition in leaves and increased the S/G unit ratio [141].

A previous work of our group applied Carbohydrate-Binding Module (CBMs) to study the effect of climate change on the accessibility of cell wall polysaccharides to hydrolytic enzymes. We found that the higher percent glucan composition, S/G ratio, higher xylose: arabinose ratio found for Guinea grass developed under warming resulted in higher surface accessibility of cellulose and xylan, enhancing the sugar yields after biomass enzymatic hydrolysis [136].

In addition, transcriptome studies demonstrated that genes of several cell-wall-related genes like those participating in cellulose, hemicellulose, and lignin biosynthesis had transcript levels impacted by heat, drought, and elevated $\mathrm{CO}_{2}[129,142-144]$. However, the literature data shows contrasting data on the gene/protein expression, which are highly dependent on the plant species, type, and intensity of the stresses applied. In this review, we focus on the most common proteins that are described to be up or downregulated under abiotic stresses.

Concerning cellulose, plants seem to respond to abiotic stress by upregulating the expression levels of cellulose synthases (CesA), sucrose synthase (Susy), UDP-Glc dehydrogenase (UGDh), and UDP-glucose pyrophosphorylase (UGPase) $[129,131,143]$. The 
Susy protein catalyzes the interconversion of sucrose into fructose and uridine diphosphate glucose (UDP-Glc) that are precursors of CW synthesis [145]. Meanwhile, Ces A, UGDh, and UGPase are key enzymes for the biosynthesis of cellulose and other non-glucosyl CW sugars via UDP-Glc; thus, the regulation of their activities might be crucial for the synthesis of xyloglucan and other relevant matrix polysaccharides [129].

Xyloglucan is an important polysaccharide present in the hemicellulose fraction of primary cell wall of major plant species [146]. The xyloglucan endotransglucosylase/endohydrolases (XTHs) are responsible for cleaving or linking hemicellulose and cellulose inducing $\mathrm{CW}$ to loosen or strengthen by changing the levels of xyloglucan polymerization [147]. Along with expansins (EXP) proteins, XTH is known to have their transcriptional levels altered helping plants to adapt under abiotic stress either by inducing cell wall loosening or by reinforcing the connections between cell wall polymers $[129,130,143]$.

Regarding lignin, a transcriptome study described in Guinea grass submitted to eTeC conditions, the downregulation of caffeic acid/5-hydroxyferulic acid O-methyltransferase 1 (COMT), an enzyme involved in lignin biosynthesis [34]. This could be a signal of a shift from lignin biosynthesis to secondary defense metabolism as a response to experienced abiotic stress and was correlated with improved maize cell wall digestibility in 30\% [148]. Other enzymes such as phenylalanine ammonia-lyase (PAL) are committed to the first step of lignin synthesis through phenylpropanoid pathway, laccases, and peroxidases (e.g., apoplastic peroxidase (PRX)) responsible for monolignols polymerization, are commonly described to have their transcriptional levels as influenced by climate changes $[129,143,149,150]$. The adjustment in the transcription levels of lignin-related enzymes is described as an adaptive mechanism to regulate cell wall expansion and prevent water losses [143].

The alterations on cell wall polymers and in the transcription levels of cell wallrelated proteins correspond to acclimation mechanisms used by plants to survive otherwise lethal abiotic stresses [129]. The results discussed in this section support the idea that tolerance mechanisms partially require cell wall-remodeling enzymes, which are involved in biosynthesis and chemical modification of cell wall polymers [131,144]. Nevertheless, most data from cell wall adjustment under climate changes come from transcriptome analysis rather than biochemical experiments. Until now, much less is known about changes in the cell wall itself, representing a challenge for a better understanding of the effects of climate change on the lignocellulosic potential for bioenergy.

Furthermore, as previously discussed in Section 7, the pretreatment step is essential for the production of fermentable sugar from lignocellulosic biomass. Nonetheless, this process alters cell wall structure, chemical composition, and association among its polymers, with the potential of influencing the climate change effect. Although warming is shown to have a positive effect on Guinea grass hydrolysis yields, the pretreatment using laccase or hydrothermal methods mitigates the climate change effects on the grass hydrolysis potential since no significant differences were found between groups grown under currently ambient conditions and eTeC treatments $[133,139]$. Therefore, integrating the effects of pretreatment and climate changes in lignocellulosic biomass must be investigated for potential biorefinery feedstocks.

Finally, to mitigate the fast climate changes and ensure sustainable agriculture and biomass production, innovative approaches must be developed to effectively meet the challenges and demands created by environmental changes. Advantage strategies such as metabolic engineering strategies, development of microbial consortium, macro- and micronutrient management, and the use of nutrient-coated nanoparticles have been successfully developed to improve growth and stress tolerance in plants [151].

\section{Conclusions and Perspectives}

The reduction in fossil-based energy consumption and its replacement by sustainable use of bioenergy is among the main options for fighting climate change reducing fossil carbon dioxide emissions to the atmosphere. Biomass production involves the capture of 
carbon from the atmosphere by the growth of biomass. However, to provide energy from biomass several processes are needed including biomass production, transport, storing, processing, conversion, and distribution. Thus, promoting the sustainable use of biomass for bioenergy requires a complete understanding of the impacts of biomass production on GHG emission, and climate change impacts on biomass production and utilization for bioenergy.

Bioenergy and food crops can be cultivated in integrated and sustainable production systems, improving land use. The stimulation of increased productivity and the use of marginal and degraded lands to dedicated energy crop production, like grasses, can reduce pressure in land use linked with bioenergy expansion and also improve carbon sequestration in soils and biomass.

Nonetheless, despite biomass availability and productivity, several factors must be considered regarding climate change. The cell wall adjustment under abiotic stress is essential in plant adaptation to environmental stresses, which directly affects the lignocellulosic potential for biorefinery. The biosynthesis of polymers and cell wall composition is dynamically regulated as a response to environmental stresses induced by climate change. Hence, since lignocellulosic biomass represents an essential alternative as energy crops, the impact of climate changes on its bioenergetic potential should be investigated. In this review, we integrate factors involved in steps for bioenergy, as pretreatment and enzymatic hydrolysis, with plant responses to climate change, showing that a complete understanding of tolerance mechanisms and climate-smart agriculture are the only way to lower the negative impact of climate changes on crop adaptation and its use for bioenergy.

Author Contributions: Conception, design, and preparation of the manuscript: E.N.d.F.; figure design and writing: R.C.A., A.G.C., J.C.S.S., E.H. and M.M.; supervision and responsible for the financial support: M.d.L.T.M.P. and C.A.M.; review and editing: M.d.L.T.M.P. All authors have read and agreed to the published version of the manuscript.

Funding: The authors thank Fundação de Amparo à Pesquisa do Estado de São Paulo (FAPESP) (Grant 2008/57908-6, 2008/58075-8, 2014/50884, 2018/07522-6, Process 2017/23989-9, 2019/07141-5, 2019/21989-7, 2020/00081-4, and 16/09742-8), and Conselho Nacional de Desenvolvimento Científico e Tecnológico (CNPq) (Grants 446357/2015-4; 465319/2014-9, 301963/2017-7).

Institutional Review Board Statement: Not applicable.

Informed Consent Statement: Not applicable.

Data Availability Statement: No new data were collected or analyzed in this study.

Acknowledgments: The authors thank the postgraduate students and laboratory technicians who contributed to the work. Figure 5 was created with BioRender.com (https: / / biorender.com, accessed on 3 November 2021).

Conflicts of Interest: The authors declare no conflict of interest.

\section{References}

1. Raza, A.; Razzaq, A.; Mehmood, S.S.; Zou, X.; Zhang, X.; Lv, Y.; Xu, J. Impact of Climate Change on Crops Adaptation and Strategies to Tackle Its Outcome: A Review. Plants 2019, 8, 34. [CrossRef]

2. Ainsworth, E.A.; Long, S.P. 30 years of free-air carbon dioxide enrichment (FACE): What have we learned about future crop productivity and its potential for adaptation? Glob. Chang. Biol. 2020, 27, 27-49. [CrossRef]

3. Gray, S.B.; Dermody, O.; Klein, S.P.; Locke, A.; McGrath, J.M.; Paul, R.E.; Rosenthal, D.M.; Vera, U.R.; Siebers, M.H.; Strellner, R.; et al. Intensifying drought eliminates the expected benefits of elevated carbon dioxide for soybean. Nat. Plants 2016, $2,16132$. [CrossRef]

4. Slattery, R.A.; Ort, D.R. Carbon assimilation in crops at high temperatures. Plant Cell Environ. 2019, 42, 2750-2758. [CrossRef] [PubMed]

5. Toor, M.; Kumar, S.; Malyan, S.K.; Bishnoi, N.R.; Mathimani, T.; Rajendran, K.; Pugazhendhi, A. An overview on bioethanol production from lignocellulosic feedstocks. Chemosphere 2020, 242, 125080. [CrossRef]

6. Amoah, J.; Kahar, P.; Ogino, C.; Kondo, A. Bioenergy and biorefinery: Feedstock, biotechnological conversion, and products. Biotechnol. J. 2019, 14, e1800494. [CrossRef] [PubMed] 
7. Da Matta, F.M.; Grandis, A.; Arenque, B.C.; Buckeridge, M.S. Impacts of climate changes on crop physiology and food quality. Food Res. Int. 2010, 43, 1814-1823. [CrossRef]

8. Polizeli, M.L.T.M.; Somera, A.F.; de Lucas, R.C.; Nozawa, M.S.F.; Michelin, M. Enzymes Involved in the Biodegradation of Sugarcane Biomass: Challenges and Perspectives. In Advances of Basic Science for Second Generation Bioethanol from Sugarcane; Buckeridge, M.S., de Souza, A.P., Eds.; Springer: Berlin/Heidelberg, Germany, 2017; pp. 55-79.

9. Monteiro, L.M.O.; Vici, A.C.; Messias, J.M.; Heinen, P.R.; Pinheiro, V.E.; Rechia, C.G.V.; Buckeridge, M.S.; Polizeli, M.L.T.M. Increased Malbranchea pulchella $\beta$-glucosidase production and its application in agroindustrial residue hydrolysis: A research based on experimental designs. Biotechnol. Rep. 2021, 30, e00618. [CrossRef]

10. Contato, A.G.; de Oliveira, T.B.; Aranha, G.M.; Freitas, E.N.; Vici, A.; Nogueira, K.M.V.; de Lucas, R.C.; Scarcella, A.; Buckeridge, M.; Silva, R.N.; et al. Prospection of fungal lignocellulolytic enzymes produced from jatoba (Hymenaea courbaril) and tamarind (Tamarindus indica) seeds: Scaling for bioreactor and saccharification profile of sugarcane bagasse. Microorganisms 2021, 9, 533. [CrossRef]

11. de Lucas, R.C.; de Oliveira, T.B.; Lima, M.S.; Pasin, T.M.; Scarcella, A.S.A.; Ribeiro, L.F.C.; Carvalho, C.; Damasio, A.R..L.; Buckeridge, M.S.; Prade, R.A.; et al. The profile secretion of Aspergillus clavatus: Different pre-treatments of sugarcane bagasse distinctly induces holocellulases for the lignocellulosic biomass conversion into sugar. Renew. Energy 2020, 165, 748-757. [CrossRef]

12. De Lucas, R.C.; De Oliveira, T.B.; Lima, M.S.; Pasin, T.; Scarcella, A.S.A.; Prade, R.A.; Segato, F.; Polizeli, M.L.T.M. Effect of enzymatic pretreatment of sugarcane bagasse with recombinant hemicellulases and esterase prior to the application of the cellobiohydrolase CBH I Megazyme ${ }^{\circledR}$. Biomass Convers. Biorefinery 2020, 1-9. [CrossRef]

13. Silva, J.C.R.; Salgado, J.C.S.; Vici, A.C.; Ward, R.J.; Polizeli, M.L.T.M.; Guimarães, L.H.S.; Furriel, R.P.M.; Jorge, J.A. A novel Trichoderma reesei mutant RP698 with enhanced cellulase production. Braz. J. Microbiol. 2020, 51, 537-545. [CrossRef]

14. Scarcella, A.S.A.; Somera, A.F.; Nunes, C.D.C.C.; Gomes, E.; Vici, A.C.; Buckeridge, M.S.; Polizeli, M.L.T.M. Matrix discriminant analysis evidenced surface-lithium as an important factor to increase the hydrolytic saccharification of sugarcane bagasse. Molecules 2019, 24, 3614. [CrossRef]

15. Scarcella, A.S.A.; Pasin, T.M.; de Oliveira, T.B.; de Lucas, R.C.; Ferreira-Nozawa, M.S.; Freitas, E.N.; Vici, A.C.; Buckeridge, M.S.; Michelin, M.; Polizeli, M.L.T.M. Saccharification of different sugarcane bagasse varieties by enzymatic cocktails produced by Mycothermus thermophilus and Trichoderma reesei RP698 cultures in agro-industrial residues. Energy 2021, 226, 120360. [CrossRef]

16. Michelin, M.; Ruiz, H.A.; Polizeli, M.L.T.M.; Teixeira, J. Multi-step approach to add value to corncob: Production of biomassdegrading enzymes, lignin and fermentable sugars. Bioresour. Technol. 2018, 247, 582-590. [CrossRef] [PubMed]

17. Pinheiro, V.E.; Horváth, I.S.; Lundin, M.; Polizeli, M.L.T.M. Screening and cocktail optimization using experimental mixture design: Enzymatic saccharification as a biological pretreatment strategy. Biofuels Bioprod. Biorefining 2021, 15, 1447-1460. [CrossRef]

18. Pasin, T.M.; Scarcella, A.S.A.; de Oliveira, T.B.; Lucas, R.C.; Cereia, M.; Betini, J.H.; Polizeli, M.L.T.M. Paper industry wastes as carbon sources for aspergillus species Cultivation and production of an enzymatic cocktail for biotechnological applications. Ind. Biotechnol. 2020, 16, 56-60. [CrossRef]

19. Pasin, T.; Salgado, J.C.S.; Scarcella, A.S.A.; De Oliveira, T.B.; De Lucas, R.C.; Cereia, M.; Rosa, J.C.; Ward, R.J.; Buckeridge, M.S.; Polizeli, M.L.T.M. A halotolerant endo-1,4- $\beta$-xylanase from Aspergillus clavatus with potential application for agroindustrial residues saccharification. Appl. Biochem. Biotechnol. 2020, 191, 1111-1126. [CrossRef]

20. Masson-Delmotte, V.; Zhai, P.; Pirani, A.; Connors, S.L.; Péan, C.; Berger, S.; Caud, N.; Chen, Y.; Goldfarb, L.; Gomis, M.I.; et al. IPCC, Summary for Policymakers. In Climate Change 2021: The Physical Science Basis. Contribution of Working Group I to the Sixth Assessment Report of the Intergovernmental Panel on Climate Change; Cambridge University Press: Cambridge, UK, 2021.

21. Perkins-Kirkpatrick, S.E.; Lewis, S.C. Increasing trends in regional heatwaves. Nat. Commun. 2020, 11, 3357. [CrossRef]

22. Coumou, D.; Rahmstorf, S. A decade of weather extremes. Nat. Clim. Chang. 2012, 2, 491-496. [CrossRef]

23. Bellard, C.; Bertelsmeier, C.; Leadley, P.; Thuiller, W.; Courchamp, F. Impacts of climate change on the future of biodiversity. Ecol. Lett. 2012, 15, 365-377. [CrossRef]

24. Hubbe, A.; Hubbe, M. Current climate change and the future of life on the planet. Front. Young Minds 2019, 7, 37. [CrossRef]

25. Feeley, K.J.; Bravo-Avila, C.; Fadrique, B.; Perez, T.M.; Zuleta, D. Climate-driven changes in the composition of New World plant communities. Nat. Clim. Chang. 2020, 10, 1-6. [CrossRef]

26. Rockström, J.; Steffen, W.; Noone, K.; Persson, Å.; Chapin, F.S., III; Lambin, E.F.; Lenton, T.M.; Scheffer, M.; Folke, C.; Schellnhuber, H.J.; et al. A safe operating space for humanity. Nature 2009, 461, 472-475. [CrossRef]

27. Steffen, W.; Richardson, K.; Rockström, J.; Cornell, S.E.; Fetzer, I.; Bennett, E.M.; Biggs, R.; Carpenter, S.R.; De Vries, W.; De Wit, C.A.; et al. Planetary boundaries: Guiding human development on a changing planet. Science 2015, 347, 1259855. [CrossRef]

28. Gatti, L.V.; Basso, L.S.; Miller, J.B.; Gloor, M.; Domingues, L.G.; Cassol, H.L.G.; Tejada, G.; Aragão, L.E.O.C.; Nobre, C.; Peters, W.; et al. Amazonia as a carbon source linked to deforestation and climate change. Nat. Cell Biol. 2021, 595, 388-393. [CrossRef]

29. Habermann, E.; de Oliveira, E.A.D.; Delvecchio, G.; Belisário, R.; Barreto, R.F.; Viciedo, D.O.; Rossingnoli, N.O.; Costa, K.A.D.P.; Prado, R.D.M.; Gonzalez-Meler, M.; et al. How does leaf physiological acclimation impact forage production and quality of a warmed managed pasture of Stylosanthes capitata under different conditions of soil water availability? Sci. Total Environ. 2021, 759, 143505. [CrossRef] [PubMed] 
30. Ainsworth, E.A.; Rogers, A. The response of photosynthesis and stomatal conductance to rising $\left[\mathrm{CO}_{2}\right]: \mathrm{Mechanisms} \mathrm{and}^{-}$ environmental interactions. Plant Cell Environ. 2007, 30, 258-270. [CrossRef] [PubMed]

31. Streck, N.A. Climate change and agroecosystems: The effect of elevated atmospheric $\mathrm{CO}_{2}$ and temperature on crop growth, development, and yield. Ciência Rural 2005, 35, 730-740. [CrossRef]

32. Habermann, E.; Martin, J.A.B.S.; Contin, D.R.; Bossan, V.P.; Barboza, A.; Braga, M.R.; Groppo, M.; Martinez, C.A. Increasing atmospheric $\mathrm{CO}_{2}$ and canopy temperature induces anatomical and physiological changes in leaves of the $\mathrm{C} 4$ forage species Panicum maximum. PLoS ONE 2019, 14, e0212506. [CrossRef] [PubMed]

33. De Souza, A.; Gaspar, M.; Da Silva, E.A.; Ulian, E.C.; Waclawovsky, A.J.; Nishiyama, M.Y.N., Jr.; Dos Santos, R.V.; Teixeira, M.M.; Souza, G.; Buckeridge, M. Elevated $\mathrm{CO}_{2}$ increases photosynthesis, biomass and productivity, and modifies gene expression in sugarcane. Plant Cell Environ. 2008, 31, 1116-1127. [CrossRef] [PubMed]

34. Wedow, J.M.; Yendrek, C.R.; Mello, T.R.; Creste, S.; Martinez, C.; Ainsworth, E.A. Metabolite and transcript profiling of Guinea grass (Panicum maximum Jacq) response to elevated $\left[\mathrm{CO}_{2}\right]$ and temperature. Metabolomics 2019, 15, 1-13. [CrossRef] [PubMed]

35. Habermann, E.; De Oliveira, E.A.D.; Contin, D.R.; Martin, J.A.B.S.; Curtarelli, L.; Gonzalez-Meler, M.; Martinez, C.A. Stomatal Development and conductance of a tropical forage legume are regulated by elevated $\left[\mathrm{CO}_{2}\right]$ under moderate warming. Front. Plant Sci. 2019, 10, 609. [CrossRef] [PubMed]

36. AbdElgawad, H.; Vignolo, E.R.F.; de Vos, D.; Asard, H. Elevated CO2 mitigates drought and temperature-induced oxidative stress differently in grasses and legumes. Plant Sci. 2015, 231, 1-10. [CrossRef] [PubMed]

37. Sage, R.F.; Kubien, D.S. The temperature response of C3 and C4 photosynthesis. Plant Cell Environ. 2007, 30, 1086-1106. [CrossRef]

38. Sage, R.F.; Way, D.A.; Kubien, D.S. Rubisco, Rubisco activase, and global climate change, J. Exp. Bot. 2008, 59, 1581-1595. [CrossRef]

39. Wahid, A.; Gelani, S.; Ashraf, M.; Foolad, M.R. Heat tolerance in plants: An overview. J. Exp. Bot. 2007, 61, 199-223. [CrossRef]

40. Carvalho, J.M.; Barreto, R.F.; Prado, R.D.M.; Habermann, E.; Branco, R.; Martinez, C. Elevated $\mathrm{CO}_{2}$ and warming change the nutrient status and use efficiency of Panicum maximum Jacq. PLoS ONE 2020, 15, e0223937. [CrossRef]

41. Leakey, A.; Ainsworth, E.A.; Bernacchi, C.; Rogers, A.; Long, S.; Ort, D.R. Elevated $\mathrm{CO}_{2}$ effects on plant carbon, nitrogen, and water relations: Six important lessons from FACE. J. Exp. Bot. 2009, 60, 2859-2876. [CrossRef]

42. Leakey, A.D.; Uribelarrea, M.; Ainsworth, E.A.; Naidu, S.L.; Rogers, A.; Ort, D.R.; Long, S. Photosynthesis, productivity, and yield of maize are not affected by open-air elevation of $\mathrm{Co}_{2}$ concentration in the absence of drought. Plant Physiol. 2006, 140, 779-790. [CrossRef]

43. Leakey, A.D.B.; Bernacchi, C.J.; Dohleman, F.G.; Ort, D.R.; Long, S.P. Will photosynthesis of maize (Zea mays ) in the US Corn Belt increase in future $\left[\mathrm{CO}_{2}\right]$ rich atmospheres? An analysis of diurnal courses of $\mathrm{CO}_{2}$ uptake under free-air concentration enrichment (FACE). Glob. Chang. Biol. 2004, 10, 951-962. [CrossRef]

44. Fay, P.A.; Polley, H.; Jin, V.L.; Aspinwall, M. Productivity of well-watered Panicum virgatum does not increase with $\mathrm{CO}_{2}$ enrichment. J. Plant Ecol. 2012, 5, 366-375. [CrossRef]

45. Vera, U.R.; Siebers, M.; Gray, S.B.; Drag, D.W.; Rosenthal, D.M.; Kimball, B.A.; Ort, D.R.; Bernacchi, C.J. Global warming can negate the expected $\mathrm{Co}_{2}$ stimulation in photosynthesis and productivity for soybean grown in the midwestern United States. Plant Physiol. 2013, 162, 410-423. [CrossRef]

46. De Oliveira, E.D.; Bramley, H.; Siddique, K.; Henty, S.; Berger, J.; Palta, J.A. Can elevated $\mathrm{CO}_{2}$ combined with high temperature ameliorate the effect of terminal drought in wheat? Funct. Plant Biol. 2013, 40, 160-171. [CrossRef]

47. De Oliveira, E.A.D.; Siddique, K.; Bramley, H.; Stefanova, K.; Palta, J.A. Response of wheat restricted-tillering and vigorous growth traits to variables of climate change. Glob. Chang. Biol. 2014, 21, 857-873. [CrossRef] [PubMed]

48. Hassan, S.; Williams, G.A.; Jaiswal, A.K. Emerging technologies for the pretreatment of lignocellulosic biomass. Bioresour. Technol. 2018, 262, 310-318. [CrossRef] [PubMed]

49. Doman, L.E.; Vipin, A.; Singer, L.E.; Zaretskaya, V.; Jones, A.; Huetteman, T.; Bowman, M.; Slater-Thompson, N.; Hojjati, B.; Peterson, D.; et al. International Energy Outlook 2016; U.S. Energy Information Administration: Washington, DC, USA, 2016.

50. De Bhowmick, G.; Sarmah, A.K.; Sen, R. Lignocellulosic biorefinery as a model for sustainable development of biofuels and value added products. Bioresour. Technol. 2018, 247, 1144-1154. [CrossRef]

51. Galbe, M.; Wallberg, O. Pretreatment for biorefineries: A review of common methods for efficient utilisation of lignocellulosic materials. Biotechnol. Biofuels 2019, 12, 1-26. [CrossRef] [PubMed]

52. Bio-Based Chemicals. Value Added Products from Biorefineries. Available online: https://www.ieabioenergy.com/wp-content/ uploads/2013/10/Task-42-Biobased-Chemicals-value-added-products-from-biorefineries.pdf (accessed on 3 November 2021).

53. Fitzpatrick, M.; Champagne, P.; Cunningham, M.F.; Whitney, R.A. A biorefinery processing perspective: Treatment of lignocellulosic materials for the production of value-added products. Bioresour. Technol. 2010, 101, 8915-8922. [CrossRef] [PubMed]

54. Wagemann, K.; Tippkötter, N. A short introduction. In Biorefineries; Springer: Berlin/Heidelberg, Germany, 2018; Volume 166, pp. 1-11.

55. Biofuel International, “Next Generation Enzymes”. Available online: https://www.dyadic.com/wp-content/uploads/2014/11/ Next-Generation-Enzymes.pdf (accessed on 4 November 2021).

56. Singhvi, M.S.; Gokhale, D.V. Lignocellulosic biomass: Hurdles and challenges in its valorization. Appl. Microbiol. Biotechnol. 2019, 103, 9305-9320. [CrossRef] 
57. Abo, B.O.; Gao, M.; Wang, Y.; Wu, C.; Ma, H.; Wang, Q. Lignocellulosic biomass for bioethanol: An overview on pretreatment, hydrolysis and fermentation processes. Rev. Environ. Health 2019, 34, 57-68. [CrossRef] [PubMed]

58. Gent, S.; Twedt, M.; Gerometta, C.; Almberg, E. Introduction to Feedstocks. In Theoretical and Applied Aspects of Biomass Torrefaction; Butterworth-Heinemann: Burlington, MA, USA, 2017; pp. 17-39.

59. Brown, T.; Wright, M.; Román-Leshkov, Y.; Brown, R. Techno-economic assessment (TEA) of advanced biochemical and thermochemical biorefineries. In Advances in Biorefineries; Woodhead Publishing: Sawston, UK, 2014; pp. 34-66.

60. Lima, A.M.; Gomez, L.D.; Steele-King, C.G.; Simister, R.; Bernardinelli, O.D.; Carvalho, A.M.; Rezende, A.C.; Labate, A.C.; Deazevedo, E.R.; McQueen-Mason, S.J.; et al. Evaluating the composition and processing potential of novel sources of Brazilian biomass for sustainable biorenewables production. Biotechnol. Biofuels 2014, 7, 10. [CrossRef]

61. Anderson, E.K.; Voigt, T.B.; Kim, S.; Lee, D. Determining effects of sodicity and salinity on switchgrass and prairie cordgrass germination and plant growth. Ind. Crop. Prod. 2015, 64, 79-87. [CrossRef]

62. Sosa, L.L.; Jozami, E.; Oakley, L.J.; Montero, G.A.; Ferreras, L.A.; Venturi, G.; Feldman, S.R. Using C4 perennial range land grasses for bioenergy. Biomass Bioenergy 2019, 128, 105299. [CrossRef]

63. Brandt, A.; Gräsvik, J.; Hallett, J.P.; Welton, T. Deconstruction of lignocellulosic biomass with ionic liquids. Green Chem. 2013, 15, 550-583. [CrossRef]

64. Menon, V.; Rao, M. Trends in bioconversion of lignocellulose: Biofuels, platform chemicals \& biorefinery concept. Prog. Energy Combust. Sci. 2012, 38, 522-550. [CrossRef]

65. Karimi, K.; Taherzadeh, M.J. A critical review of analytical methods in pretreatment of lignocelluloses: Composition, imaging, and crystallinity. Bioresour. Technol. 2016, 200, 1008-1018. [CrossRef] [PubMed]

66. Chundawat, S.P.; Beckham, G.T.; Himmel, M.E.; Dale, B.E. Deconstruction of lignocellulosic biomass to fuels and chemicals. Annu. Rev. Chem. Biomol. Eng. 2011, 2, 121-145. [CrossRef] [PubMed]

67. Liu, Q.; Luo, L.; Zheng, L. Lignins: Biosynthesis and biological functions in plants. Int. J. Mol. Sci. 2018, 19, 335. [CrossRef]

68. Zhang, Y.-H.P. Reviving the carbohydrate economy via multi-product lignocellulose biorefineries. J. Ind. Microbiol. Biotechnol. 2008, 35, 367-375. [CrossRef] [PubMed]

69. Oliveira, D.M.; Finger-Teixeira, A.; Mota, T.; Salvador, V.H.; Moreira-Vilar, F.C.; Molinari, H.B.C.; Mitchell, R.; Marchiosi, R.; Ferrarese-Filho, O.; Dos Santos, W.D. Ferulic acid: A key component in grass lignocellulose recalcitrance to hydrolysis. Plant Biotechnol. J. 2014, 13, 1224-1232. [CrossRef]

70. Hong, J.; Ye, A.X.; Zhang, Y.-H.P. quantitative determination of cellulose accessibility to cellulase based on adsorption of a nonhydrolytic fusion protein containing CBM and GFP with its applications. Langmuir 2007, 23, 12535-12540. [CrossRef] [PubMed]

71. Yang, B.; Dai, Z.; Ding, S.-Y.; Wyman, E.C. Enzymatic hydrolysis of cellulosic biomass. Biofuels 2011, 2, 421-449. [CrossRef]

72. Sindhu, R.; Binod, P.; Pandey, A. Biological pretreatment of lignocellulosic biomass-An overview. Bioresour. Technol. 2016, 199, 76-82. [CrossRef]

73. Adsul, M.; Sandhu, S.K.; Singhania, R.R.; Gupta, R.; Puri, S.K.; Mathur, A. Designing a cellulolytic enzyme cocktail for the efficient and economical conversion of lignocellulosic biomass to biofuels. Enzym. Microb. Technol. 2020, 133, 109442. [CrossRef] [PubMed]

74. Jönsson, L.J.; Alriksson, B.; Nilvebrant, N.-O. Bioconversion of lignocellulose: Inhibitors and detoxification. Biotechnol. Biofuels 2013, 6, 16. [CrossRef]

75. Raghavi, S.; Sindhu, R.; Binod, P.; Gnansounou, E.; Pandey, A. Development of a novel sequential pretreatment strategy for the production of bioethanol from sugarcane trash. Bioresour. Technol. 2016, 199, 202-210. [CrossRef]

76. Lavoie, J.-M.; Capek-Menard, E.; Gauvin, H.; Chornet, E. Production of pulp from Salix viminalis energy crops using the FIRSST process. Bioresour. Technol. 2010, 101, 4940-4946. [CrossRef]

77. Kong, W.; Fu, X.; Wang, L.; Alhujaily, A.; Zhang, J.; Ma, F.; Zhang, X.; Yu, H. A novel and efficient fungal delignification strategy based on versatile peroxidase for lignocellulose bioconversion. Biotechnol. Biofuels 2017, 10, 218. [CrossRef] [PubMed]

78. Guo, H.; Chang, Y.; Lee, D.-J. Enzymatic saccharification of lignocellulosic biorefinery: Research focuses. Bioresour. Technol. 2018, 252, 198-215. [CrossRef]

79. Li, M.-F.; Yang, S.; Sun, R.-C. Recent advances in alcohol and organic acid fractionation of lignocellulosic biomass. Bioresour. Technol. 2016, 200, 971-980. [CrossRef] [PubMed]

80. Li, Y.; Liu, C.; Bai, F.; Zhao, X. Overproduction of cellulase by Trichoderma reesei RUT C30 through batch-feeding of synthesized low-cost sugar mixture. Bioresour. Technol. 2016, 216, 503-510. [CrossRef] [PubMed]

81. Bhatia, R.; Winters, A.; Bryant, D.N.; Bosch, M.; Clifton-Brown, J.; Leak, D.; Gallagher, J. Pilot-scale production of xylooligosaccharides and fermentable sugars from Miscanthus using steam explosion pretreatment. Bioresour. Technol. 2020, 296, 122285. [CrossRef] [PubMed]

82. Chen, Z.; Wan, C. Ultrafast fractionation of lignocellulosic biomass by microwave-assisted deep eutectic solvent pretreatment. Bioresour. Technol. 2018, 250, 532-537. [CrossRef]

83. Chen, Z.; Reznicek, W.D.; Wan, C. Deep eutectic solvent pretreatment enabling full utilization of switchgrass. Bioresour. Technol. 2018, 263, 40-48. [CrossRef]

84. Santos, C.C.; de Souza, W.; 'Anna, C.S.; Brienzo, M. Elephant grass leaves have lower recalcitrance to acid pretreatment than stems, with higher potential for ethanol production. Ind. Crop. Prod. 2018, 111, 193-200. [CrossRef] 
85. Toscan, A.; Morais, A.; Paixão, S.M.; Alves, S.P.; Andreaus, J.; Camassola, M.; Dillon, A.J.P.; Lukasik, R.M. High-pressure carbon dioxide/water pre-treatment of sugarcane bagasse and elephant grass: Assessment of the effect of biomass composition on process efficiency. Bioresour. Technol. 2017, 224, 639-647. [CrossRef]

86. Guo, H.; Zhao, Y.; Chen, X.; Shao, Q.; Qin, W. Pretreatment of Miscanthus with biomass-degrading bacteria for increasing delignification and enzymatic hydrolysability. Microb. Biotechnol. 2019, 12, 787-798. [CrossRef]

87. Marques, S.; Alves, L.; Roseiro, J.; Gírio, F. Conversion of recycled paper sludge to ethanol by SHF and SSF using Pichia stipitis. Biomass Bioenergy 2008, 32, 400-406. [CrossRef]

88. Soleimani, S.; Ranaei-Siadat, S.-O. Preparation and optimization of cellulase cocktail to improve the bioethanol process. Biofuels 2017, 8, 291-296. [CrossRef]

89. Chandel, A.K.; Albarelli, J.Q.; Santos, D.T.; Chundawat, S.; Puri, M.; Meireles, M.A.A. Comparative analysis of key technologies for cellulosic ethanol production from Brazilian sugarcane bagasse at a commercial scale. Biofuels Bioprod. Biorefining 2019, 13, 994-1014. [CrossRef]

90. Kumar, A. Biomass breakdown A review on pretreatment instrumentations and methods. Front. Biosci. 2018, 10, 155-174. [CrossRef] [PubMed]

91. Polizeli, M.L.T.M.; Vici, A.; Scarcella, A.; Cereia, M.; Pereira, M. Enzyme System from Aspergillus in Current Industrial Uses and Future Applications in the Production of Second-Generation Ethanol; Elsevier BV: Amsterdam, The Netherlands, 2016 ; pp. 127-140.

92. Himmel, M.E.; Ding, S.-Y.; Johnson, D.K.; Adney, W.S.; Nimlos, M.R.; Brady, J.W.; Foust, T.D. Biomass recalcitrance: Engineering plants and enzymes for biofuels production. Science 2007, 315, 804-807. [CrossRef]

93. Heinen, P.R.; Bauermeister, A.; Ribeiro, L.; Messias, J.; Almeida, P.; Moraes, L.A.; Vargas-Rechia, C.; de Oliveira, A.; Ward, R.; Filho, E.; et al. GH11 xylanase from Aspergillus tamarii Kita: Purification by one-step chromatography and xylooligosaccharides hydrolysis monitored in real-time by mass spectrometry. Int. J. Biol. Macromol. 2018, 108, 291-299. [CrossRef]

94. Carapito, R.; Imberty, A.; Jeltsch, J.-M.; Byrns, S.C.; Tam, P.-H.; Lowary, T.; Varrot, A.; Phalip, V. molecular basis of arabinobiohydrolase activity in phytopathogenic fungi. J. Biol. Chem. 2009, 284, 12285-12296. [CrossRef]

95. Saha, B.C. $\alpha$-l-Arabinofuranosidases: Biochemistry, molecular biology and application in biotechnology. Biotechnol. Adv. 2000, 18, 403-423. [CrossRef]

96. Nasseri, S.A.; Betschart, L.; Opaleva, D.; Rahfeld, P.; Withers, S.G. A Mechanism-Based Approach to Screening Metagenomic Libraries for Discovery of Unconventional Glycosidases. Angew. Chem. 2018, 130, 11529-11534. [CrossRef]

97. Pasin, T.M.; de Almeida, P.Z.; Scarcella, A.S.D.A.; Infante, J.D.C.; Polizeli, M.L.D.T.M. Bioconversion of agro-industrial residues to second-generation bioethanol. In Biorefinery of Alternative Resources: Targeting Green Fuels and Platform Chemicals; Springer: Berlin/Heidelberg, Germany, 2020; pp. 23-47.

98. Haddad Momeni, M.; Fredslund, F.; Bissaro, B.; Raji, O.; Vuong, T.V.; Meier, S.; Nielsen, T.S.; Lombard, V.; Guigliarelli, B.; Biaso, F.; et al. Discovery of fungal oligosaccharide-oxidising flavo-enzymes with previously unknown substrates, redox-activity profiles and interplay with LPMOs. Nat. Commun. 2021, 12, 2132. [CrossRef] [PubMed]

99. Müller, G.; Chylenski, P.; Bissaro, B.; Eijsink, V.G.H.; Horn, S.J. The impact of hydrogen peroxide supply on LPMO activity and overall saccharification efficiency of a commercial cellulase cocktail. Biotechnol. Biofuels 2018, 11, 1-17. [CrossRef] [PubMed]

100. Hu, J.; Arantes, V.; Pribowo, A.; Gourlay, K.; Saddler, J.N. Substrate factors that influence the synergistic interaction of AA9 and cellulases during the enzymatic hydrolysis of biomass. Energy Environ. Sci. 2014, 7, 2308-2315. [CrossRef]

101. Biely, P.; Mastihubová, M.; Tenkanen, M.; Eyzaguirre, J.; Li, X.-L.; Vršanská, M. Action of xylan deacetylating enzymes on monoacetyl derivatives of 4-nitrophenyl glycosides of $\beta$-D-xylopyranose and $\alpha$-l-arabinofuranose. J. Biotechnol. 2011, 151, 137-142. [CrossRef] [PubMed]

102. Qin, Y.-M.; Tao, H.; Liu, Y.-Y.; Wang, Y.-D.; Zhang, J.-R.; Tang, A.-X. A novel non-hydrolytic protein from Pseudomonas oryzihabitans enhances the enzymatic hydrolysis of cellulose. J. Biotechnol. 2013, 168, 24-31. [CrossRef] [PubMed]

103. Morrison, J.M.; Elshahed, M.S.; Youssef, N.H. Defined enzyme cocktail from the anaerobic fungus Orpinomyces sp. strain C1A effectively releases sugars from pretreated corn stover and switchgrass. Sci. Rep. 2016, 6, 29217. [CrossRef]

104. Su, Y.; Yu, X.; Sun, Y.; Wang, G.; Chen, H.; Chen, G. Evaluation of screened lignin-degrading fungi for the biological pretreatment of corn stover. Sci. Rep. 2018, 8, 1-11. [CrossRef] [PubMed]

105. Oliva-Taravilla, A.; Tomás-Pejó, E.; Demuez, M.; González-Fernández, C.; Ballesteros, M. Inhibition of cellulose enzymatic hydrolysis by laccase-derived compounds from phenols. Biotechnol. Prog. 2015, 31, 700-706. [CrossRef]

106. Devireddy, A.R.; Tschaplinski, T.J.; Tuskan, G.A.; Muchero, W.; Chen, J.-G. Role of reactive oxygen species and hormones in plant responses to temperature changes. Int. J. Mol. Sci. 2021, 22, 8843. [CrossRef]

107. Challinor, A.; Watson, J.; Lobell, D.; Howden, S.; Smith, D.R.; Chhetri, N. A meta-analysis of crop yield under climate change and adaptation. Nat. Clim. Chang. 2014, 4, 287-291. [CrossRef]

108. Asseng, S.; Ewert, F.; Martre, P.; Rötter, R.P.; Lobell, D.B.; Cammarano, D.; Kimball, B.A.; Ottman, M.J.; Wall, G.W.; White, J.W.; et al. Rising temperatures reduce global wheat production. Nat. Clim. Chang. 2015, 5, 143-147. [CrossRef]

109. Ferreira, T.H.S.; Tsunada, M.S.; Bassi, D.; Araujo, P.; Mattiello, L.; Guidelli, G.V.; Righetto, G.L.; Gonçalves, V.R.; Lakshmanan, P.; Menossi, M. Sugarcane water stress tolerance mechanisms and its implications on developing biotechnology solutions. Front. Plant Sci. 2017, 8, 1077. [CrossRef]

110. Anwar, K.; Joshi, R.; Dhankher, O.; Singla-Pareek, S.; Pareek, A. Elucidating the response of crop plants towards individual, combined and sequentially occurring abiotic stresses. Int. J. Mol. Sci. 2021, 22, 6119. [CrossRef] 
111. Prasad, V.B.R.; Govindaraj, M.; Djanaguiraman, M.; Djalovic, I.; Shailani, A.; Rawat, N.; Singla-Pareek, S.L.; Pareek, A.; Prasad, P.V.V. Drought and high temperature stress in sorghum: Physiological, genetic, and molecular insights and breeding approaches. Int. J. Mol. Sci. 2021, 22, 9826. [CrossRef]

112. Zhao, C.; Liu, B.; Piao, S.; Wang, X.; Lobell, D.B.; Huang, Y.; Huang, M.; Yao, Y.; Bassu, S.; Ciais, P.; et al. Temperature increase reduces global yields of major crops in four independent estimates. Proc. Natl. Acad. Sci. USA 2017, 114, 9326-9331. [CrossRef] [PubMed]

113. Hatfield, J.L.; Boote, K.J.; Kimball, B.A.; Ziska, L.H.; Izaurralde, R.C.; Ort, D.; Thomson, A.M.; Wolfe, D. Climate impacts on agriculture: Implications for crop production. Agron. J. 2011, 103, 351-370. [CrossRef]

114. Sicher, R.C.; Bunce, J.A. The Impact of Enhanced Atmospheric $\mathrm{Co}_{2}$ concentrations on the responses of maize and soybean to elevated growth temperatures. In Combined Stresses in Plants; Springer: Berlin/Heidelberg, Germany, 2014; pp. 27-48.

115. Hussain, H.A.; Men, S.; Hussain, S.; Chen, Y.; Ali, S.; Zhang, S.; Zhang, K.; Li, Y.; Xu, Q.; Liao, C.; et al. Interactive effects of drought and heat stresses on morpho-physiological attributes, yield, nutrient uptake and oxidative status in maize hybrids. Sci. Rep. 2019, 9, 1-12. [CrossRef]

116. Sattar, A.; Sher, A.; Ijaz, M.; Ul-Allah, S.; Rizwan, M.S.; Hussain, M.; Jabran, K.; Cheema, M.A. Terminal drought and heat stress alter physiological and biochemical attributes in flag leaf of bread wheat. PLoS ONE 2020, 15, e0232974. [CrossRef]

117. Habermann, E.; De Oliveira, E.A.D.; Contin, D.R.; DelVecchio, G.; Viciedo, D.O.; De Moraes, M.A.; Prado, R.D.M.; Costa, K.; Braga, M.R.; Martinez, C.A. Warming and water deficit impact leaf photosynthesis and decrease forage quality and digestibility of a C4 tropical grass. Physiol. Plant. 2019, 165, 383-402. [CrossRef] [PubMed]

118. Prado, C.H.B.D.A.; De Camargo-Bortolin, L.H.G.; Castro, É.; Martínez, C.A. Leaf dynamics of Panicum maximum under future climatic changes. PLoS ONE 2016, 11, e0149620. [CrossRef]

119. Dias de Oliveira, E.A.; Manchon, F.T.; Ricketts, M.P.; Bianconi, M.; Martinez, C.A.; Gonzalez-Meler, M. Plant diurnal cycle drives the variation in soil respiration in a C4-dominated tropical managed grassland exposed to high $\mathrm{CO}_{2}$ and warming. Plant Soil 2020, 456, 391-404. [CrossRef]

120. Looby, C.I.; Treseder, K.K. Shifts in soil fungi and extracellular enzyme activity with simulated climate change in a tropical montane cloud forest. Soil Biol. Biochem. 2018, 117, 87-96. [CrossRef]

121. Schmidt, P.-A.; Schmitt, I.; Otte, J.; Bandow, C.; Römbke, J.; Bálint, M.; Rolshausen, G. Season-long experimental drought alters fungal community composition but not diversity in a grassland soil. Microb. Ecol. 2017, 75, 468-478. [CrossRef] [PubMed]

122. Solly, E.F.; Lindahl, B.D.; Dawes, M.A.; Peter, M.; Souza, R.C.; Rixen, C.; Hagedorn, F. Experimental soil warming shifts the fungal community composition at the alpine treeline. New Phytol. 2017, 215, 766-778. [CrossRef] [PubMed]

123. De Oliveira, T.B.; De Lucas, R.C.; Scarcella, A.S.A.; Contato, A.G.; Pasin, T.; Martinez, C.; Polizeli, M.L.T.M. Fungal communities differentially respond to warming and drought in tropical grassland soil. Mol. Ecol. 2020, 29, 1550-1559. [CrossRef]

124. Aoki, T.; O'Donnell, K.; Geiser, D.M. Systematics of key phytopathogenic Fusarium species: Current status and future challenges. J. Gen. Plant Pathol. 2014, 80, 189-201. [CrossRef]

125. Matić, S.; Gilardi, G.; Gullino, M.L.; Garibaldi, A. Emergence of leaf spot disease on leafy vegetable and ornamental crops caused by Paramyrothecium and Albifimbria Species. Phytopathology 2019, 109, 1053-1061. [CrossRef] [PubMed]

126. De Oliveira, T.B.; De Lucas, R.C.; Scarcella, A.S.A.; Pasin, T.; Martinez, C.; Polizeli, M.L.T.M. Perspectives on exploring denitrifying fungi as a model to evaluate nitrous oxide production and reduce emissions from agricultural soils. J. Agric. Food Chem. 2019, 67, 12153-12154. [CrossRef] [PubMed]

127. Viciedo, D.O.; Prado, R.D.M.; Martinez, C.; Habermann, E.; Piccolo, M.D.C. Short-term warming and water stress affect Panicum maximum Jacq. stoichiometric homeostasis and biomass production. Sci. Total Environ. 2019, 681, 267-274. [CrossRef] [PubMed]

128. Oliveira, D.M.; Mota, T.R.; Salatta, F.V.; Sinzker, R.C.; Končitíková, R.; Kopečný, D.; Simister, R.; Silva, M.; Goeminne, G.; Morreel, K.; et al. Cell wall remodeling under salt stress: Insights into changes in polysaccharides, feruloylation, lignification, and phenolic metabolism in maize. Plant Cell Environ. 2020, 43, 2172-2191. [CrossRef] [PubMed]

129. Warming, G. Plant cell walls tackling climate change: Biotechnological strategies to improve crop adaptations and photosynthesis in response to global warming. Plants 2020, 9, 212. [CrossRef]

130. Moura, J.C.M.S.; Bonine, C.A.V.; de Oliveira Fernandes Viana, J.; Dornelas, M.C.; Mazzafera, P. Abiotic and biotic stresses and changes in the lignin content and composition in plants. J. Integr. Plant Biol. 2010, 52, 360-376. [CrossRef]

131. Tenhaken, R. Cell wall remodeling under abiotic stress. Front. Plant Sci. 2015, 5, 771. [CrossRef]

132. Wang, T.; McFarlane, H.E.; Persson, S. The impact of abiotic factors on cellulose synthesis. J. Exp. Bot. 2015, 67, 543-552. [CrossRef]

133. Freitas, E.N.; Khatri, V.; Wu, J.; Takada, M.; de Scarcella, A.S.; Martinez, C.A.; Saddler, J.N.; Polizeli, M.L.T.M. Structural and compositional changes induced by hydrothermal and organosolv pretreatments impacts enzymatic hydrolysis of a tropical forage grass grown under future climate conditions. Ind. Crop. Prod. 2021, 171, 113937. [CrossRef]

134. Teng, N.; Wang, J.; Chen, T.; Wu, X.; Wang, Y.; Lin, J. Elevated $\mathrm{CO}_{2}$ induces physiological, biochemical and structural changes in leaves of Arabidopsis thaliana. New Phytol. 2006, 172, 92-103. [CrossRef] [PubMed]

135. Lima, R.; Santos, T.; Vieira, L.G.E.; Ferrarese, M.D.L.L.; Ferrarese-Filho, O.; Donatti, L.; Boeger, M.R.T.B.; Petkowicz, C. Heat stress causes alterations in the cell-wall polymers and anatomy of coffee leaves (Coffea arabica L.). Carbohydr. Polym. 2013, 93, 135-143. [CrossRef] 
136. Freitas, E.N.; Khatri, V.; Contin, D.; Oliveira, T.; Contato, A.G.; Peralta, R.M.; dos Santos, W.D.; Martínez, C.A.; Saddler, J.; Polizeli, M.L.T.M. Climate change affects cell wall structure and hydrolytic performance of a tropical forage grass as an energy crop. Biofuels Bioprod. Biorefining 2021. [CrossRef]

137. Rakszegi, M.; Lovegrove, A.; Balla, K.; Láng, L.; Bedő, Z.; Veisz, O.; Shewry, P.R. Effect of heat and drought stress on the structure and composition of arabinoxylan and $\beta$-glucan in wheat grain. Carbohydr. Polym. 2014, 102, 557-565. [CrossRef] [PubMed]

138. Hatfield, R.D.; Rancour, D.M.; Marita, J.M. Grass cell walls: A story of cross-linking. Front. Plant Sci. 2017, 7, 2056. [CrossRef]

139. Freitas, E.N.; Alnoch, R.C.; Contato, A.G.; Nogueira, K.M.V.; Crevelin, E.J.; de Moraes, L.A.B.; Silva, R.N.; Martínez, C.A.; Polizeli, M.L.T.M. Enzymatic pretreatment with laccases from Lentinus sajor-caju induces structural modification in lignin and enhances the digestibility of tropical forage grass (Panicum maximum) grown under future climate conditions. Int. J. Mol. Sci. 2021, $22,9445$. [CrossRef]

140. Lee, M.A.; Davis, A.P.; Chagunda, M.G.G.; Manning, P. Forage quality declines with rising temperatures, with implications for livestock production and methane emissions. Biogeosciences 2017, 14, 1403-1417. [CrossRef]

141. Moura-Sobczak, J.; Souza, U.; Mazzafera, P. Drought stress and changes in the lignin content and composition in Eucalyptus. BMC Proc. 2011, 5, P103. [CrossRef]

142. Zhu, J.; Lee, B.-H.; Dellinger, M.; Cui, X.; Zhang, C.; Wu, S.; Nothnagel, E.A.; Zhu, J.-K. A cellulose synthase-like protein is required for osmotic stress tolerance in Arabidopsis. Plant J. 2010, 63, 128-140. [CrossRef]

143. Le Gall, H.; Philippe, F.; Domon, J.-M.; Gillet, F.; Pelloux, J.; Rayon, C. Cell wall metabolism in response to abiotic stress. Plants 2015, 4, 112-166. [CrossRef]

144. Houston, K.; Tucker, M.; Chowdhury, J.; Shirley, N.; Little, A. The plant cell wall: A complex and dynamic structure as revealed by the responses of genes under stress conditions. Front. Plant Sci. 2016, 7, 984. [CrossRef] [PubMed]

145. Persia, D.; Cai, G.; Del Casino, C.; Faleri, C.; Willemse, M.T.; Cresti, M. Sucrose synthase is associated with the cell wall of tobacco pollen tubes. Plant Physiol. 2008, 147, 1603-1618. [CrossRef] [PubMed]

146. Méndez-Yañez, Á.; Beltrán, D.; Campano-Romero, C.; Molinett, S.; Herrera, R.; Moya-León, M.A.; Morales-Quintana, L. Glycosylation is important for FcXTH1 activity as judged by its structural and biochemical characterization. Plant Physiol. Biochem. 2017, 119, 200-210. [CrossRef]

147. Campbell, P.; Braam, J. In vitro activities of four xyloglucan endotransglycosylases from Arabidopsis. Plant J. 1999, 18, $371-382$. [CrossRef]

148. Guillaumie, S.; Goffner, D.; Barbier, O.; Martinant, J.-P.; Pichon, M.; Barrière, Y. Expression of cell wall related genes in basal and ear internodes of silking brown-midrib-3, caffeic acid O-methyltransferase (COMT) down-regulated, and normal maize plants. BMC Plant Biol. 2008, 8, 71. [CrossRef]

149. Wang, Y.; Chantreau, M.; Sibout, R.; Hawkins, S. Plant cell wall lignification and monolignol metabolism. Front. Plant Sci. 2013, 4, 220. [CrossRef]

150. Cass, C.L.; Peraldi, A.; Dowd, P.F.; Mottiar, Y.; Santoro, N.; Karlen, S.D.; Bukhman, Y.V.; Foster, C.E.; Thrower, N.; Bruno, L.C.; et al. Effects of phenylalanine ammonia lyase(pal) knockdown on cell wall composition, biomass digestibility, and biotic and abiotic stress responses inBrachypodium. J. Exp. Bot. 2015, 66, 4317-4335. [CrossRef] [PubMed]

151. Shahinnia, F.; Carrillo, N.; Hajirezaei, M.-R. Engineering climate-change-resilient crops: New tools and approaches. Int. J. Mol. Sci. 2021, 22, 7877. [CrossRef] [PubMed] 